\title{
Postępowanie terapeutyczne w zespołach mielodysplastycznych niższego ryzyka
}

\section{A therapeutic approach to lower-risk myelodysplastic syndromes}

\author{
Kamil Wiśniewski ${ }^{1}$ (D), Aleksandra Gołos ${ }^{2}$ (D) Joanna Góra-Tybor ${ }^{3}$ (D) \\ ${ }^{1}$ Klinika Hematologii Instytutu Hematologii i Transfuzjologii w Warszawie \\ ${ }^{2}$ Oddział Onkologii Klinicznej i Chemioterapii, Luxmed Onkologia, Szpital Szamocka \\ ${ }^{3}$ Klinika Hematologii Uniwersytetu Medycznego w Łodzi
}

\begin{abstract}
Streszczenie
Zespoty mielodysplastyczne (MDS) sa grupa nabytych klonalnych zaburzeń uktadu krwiotwórczego spowodowanych mutacja krwiotwórczych komórek macierzystych szpiku. W zależności od parametrów klinicznych i laboratoryjnych MDS dzieli sie na grupy niskiego (LR-MDS) $i$ wysokiego (HR-MDS) ryzyka, co determinuje rodzaj postepowania terapeutycznego. W ostatnich latach, w wyniku rejestracji nowych leków oraz coraz nowocześniejszych metod leczenia wspomagajacego, obserwuje sie wydtużenie życia i poprawe jego jakości u chorych na MDS. W artykule przedstawiono aktualne dane dotyczqce postepowania diagnostycznego i terapeutycznego w LR-MDS z uwzglednieniem najnowszych zarejestrowanych metod terapii. Ponadto omówiono leczenie wspomagajace i terapie będace $w$ fazie badań klinicznych.
\end{abstract}

\section{Słowa kluczowe: MDS niskiego ryzyka, diagnostyka MDS, leczenie MDS niskiego ryzyka}

Hematologia 2020; 11, 4: 219-234

\begin{abstract}
Myelodysplastic syndromes (MDS) are acquired clonal disorders of the hematopoietic system caused by a mutation in hematopoietic stem cells. Depending on clinical and laboratory parameters, MDS is divided into two subgroups: low-risk MDS (LR-MDS) and high-risk MDS (HR-MDS), which determines a range of therapeutic options. Recently, some progress in prolongation and quality of life has been observed, mainly due to new therapeutic and supportive methods. The article provides an overview of the current diagnostic and therapeutic approach to lower-risk MDS, as well as manifests the most recent registered therapeutic methods. Additionally, the paper reviews supportive treatment and drugs in clinical trials.
\end{abstract}

Key words: low-risk MDS, MDS diagnosis, low-risk MDS treatment

Hematologia 2020; 11, 4: 219-234

\section{Wprowadzenie}

Zespoły mielodysplastyczne (MDS, myelodysplastic syndromes) są heterogenną grupą nabytych klonalnych zaburzeń układu krwiotwórcze- go powstających na skutek mutacji somatycznej w krwiotwórczych komórkach macierzystych szpiku [1]. Nieprawidłowe klony komórek zajmują szpik kostny i wypierają prawidłową hematopoezę. Cechą charakterystyczną MDS są cytopenie

Adres do korespondencji: Aleksandra Gołos, Oddział Onkologii Klinicznej i Chemioterapii Szpitala Szamocka, Luxmed Onkologia, ul. Szamocka 6, 01-748 Warszawa, e-mail: alexandra_golos@tlen.pl 
we krwi obwodowej oraz zmiany dysplastyczne w komórkach krwi i szpiku kostnego. Przebieg choroby jest bardzo heterogenny — od bezobjawowych, lagodnych cytopenii do postaci z gwałtownie postępującymi objawami klinicznymi i wysokim ryzykiem transformacji do ostrej białaczki szpikowej (AML, acute myeloid leukemia). Ze względu na duże zróżnicowanie przebiegu klinicznego pacjenci z MDS wymagają bardzo zindywidualizowanego podejścia do leczenia. Oprócz stanu klinicznego chorego, wieku i obecności chorób wspólistniejących podstawą decyzji terapeutycznych jest ocena ryzyka choroby zgodna $z$ obowiązującymi skalami prognostycznymi [2].

W przypadku pacjentów z MDS niższego ryzyka (LR-MDS, low-risk myelodysplastic syndromes), $z$ przewidywanym stosunkowo długim czasem przeżycia, celem leczenia pozostaje głównie poprawa parametrów krwi obwodowej, przede wszystkim niedokrwistości. Celami metod leczenia stosowanych w MDS wyższego ryzyka (HR-MDS, high-risk myelodysplastic syndromes), tj. leczenia hipometylującego, intensywnej chemioterapii czy allogenicznego przeszczepienia komórek krwiotwórczych szpiku (allo-HSCT, allogeneic hematopoietic stem cell transplantation), są wydłużenie przeżycia całkowitego (OS, overall survival) i obniżenie ryzyka transformacji do AML [3].

$\mathrm{W}$ ostatnich latach, w wyniku rejestracji nowych leków oraz coraz lepszych metod leczenia wspomagającego, obserwuje się poprawę długości i jakości życia chorych na MDS. W niniejszym artykule przedstawiono aktualne metody postępowania w LR-MDS oraz nowe terapie pozostające jeszcze w fazie badań klinicznych.

\section{Diagnostyka}

Pierwszym etapem diagnostyki MDS jest ocena morfologii krwi obwodowej wraz z rozmazem mikroskopowym, umożliwiająca wykazanie cytopenii, cech dysplazji oraz obecności mieloblastów. Warunek wstępny rozpoznania to stwierdzenie utrzymującej się cytopenii we krwi obwodowej wraz z jednoczesnym wykluczeniem stanów innych niż MDS, mogących powodować dysplazję lub cytopenie [1]. Do najczęstszych przyczyn wtórnych dysplazji i cytopenii należą stany niedoborowe, działanie leków i substancji toksycznych oraz przewlekłe stany zapalne. Przedmiotem dyskusji pozostaje stopień nasilenia oraz czas trwania cytopenii pozwalający na rozpoznanie MDS. W najnowszych, zaktualizowanych minimalnych kryteriach diagnostycznych MDS za wystarczający przyjęto 4-miesięczny czas trwania niedokrwistości, małopłytkowości i/lub neutropenii [4]. Kolejnym etapem diagnostyki jest badanie szpiku kostnego. Badanie mikroskopowe aspiratu szpiku kostnego umożliwia ocenę komórkowości, cech dysplazji oraz wykazanie obecności mieloblastów i syderoblastów pierścieniowatych. Prawidłowa ocena mielogramu powinna obejmować co najmniej 500 komórek jądrzastych, w tym 100 erytroblastów i 30 megakariocytów. Badanie histopatologiczne trepanobioptatu, oprócz oceny liczby i morfologii komórek, pozwala na ocenę włóknienia szpiku oraz wykluczenie wtórnych przyczyn cytopenii. Kryterium swoistym dla MDS pozostaje obecność dysplazji w co najmniej $10 \%$ komórek linii erytropoetycznej, granulocytarnej i/lub megakariopoetycznej. Diagnostykę uzupełnia klasyczne badanie cytogenetyczne, pozwalające stwierdzić nieprawidłowości cytogenetyczne typowe dla MDS, w tym del(5q), del(7q) czy monosomię chromosomu 7. Zaburzenia kariotypu, najczęściej delecje i monosomie, są wykrywane u około połowy pacjentów $z$ pierwotnym MDS i nawet u $80 \%$ $z$ wtórnym MDS [5-7]. Ocena kariotypu powinna zostać przeprowadzana u wszystkich pacjentów. $\mathrm{W}$ ostatnich latach badania molekularne odgrywają coraz ważniejszą rolę w diagnostyce tego zespołu. Powtarzalne mutacje somatyczne wykrywa się nawet u 80-90\% chorych na MDS [8]. U wszystkich chorych należy wykonać badanie w kierunku obecności mutacji $S F 3 B 1$, gdyż jej stwierdzenie umożliwia rozpoznanie MDS z obecnością pierścieniowatych syderoblastów (MDS-RS, MDS with ring sideroblasts) już przy $5 \%$ syderoblastów pierścieniowatych. W MDS $z$ del(5q) jest wskazane oznaczenie mutacji TP53 ze względu na jej niekorzystne znaczenie rokownicze (krótszy czas odpowiedzi na lenalidomid, wyższe ryzyko transformacji do AML) [9]. Z kolei stwierdzenie obecności mutacji $I D H 1 / 2$, zważywszy na dostępność inhibitorów enasidenibu/ /iwosidenibu, może mieć znaczenie przy wyborze terapii $[10,11]$.

\section{Klasyfikacja Światowej Organizacji Zdrowia}

Przeprowadzenie pełnej diagnostyki MDS umożliwia rozpoznanie choroby zgodnie $z$ obowiązującą klasyfikacją Światowej Organizacji Zdrowia (WHO, World Health Organization) z 2016 roku (tab. 1) [1]. W klasyfikacji tej zdefiniowano podtypy MDS, uwzględniając liczbę linii komórkowych wykazujących cechy dysplazji, odsetek blastów w krwi obwodowej i szpiku kostnym, występowanie 
Tabela 1. Podział zespołów mielodysplastycznych (MDS) na podstawie klasyfikacji Światowej Organizacji Zdrowia z 2016 roku (na podstawie [1])

Table 1. Myelodysplastic syndromes (MDS) classification according to World Health Organization classification 2016 (based on [1])

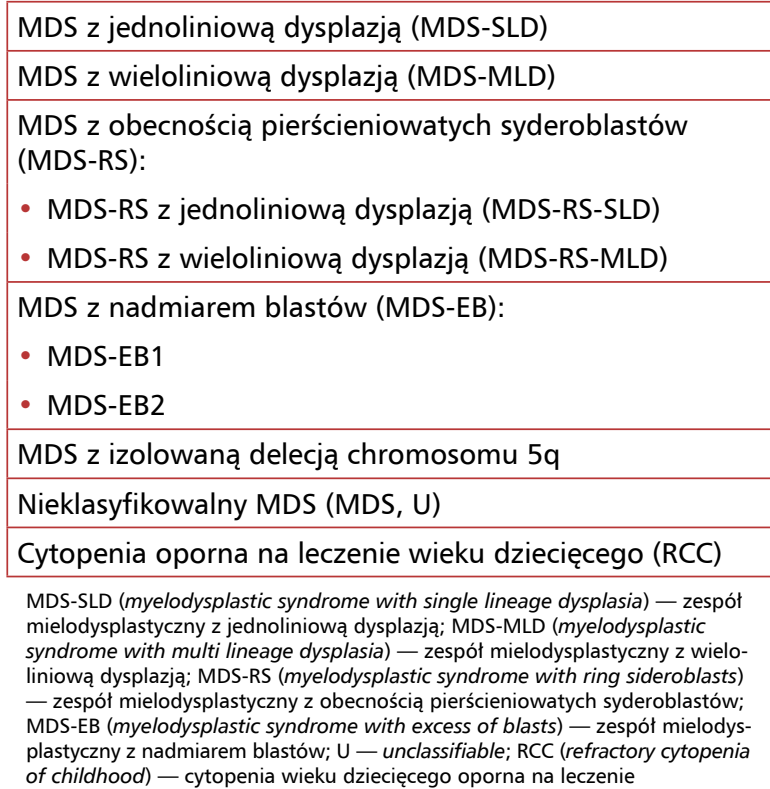

typowych zaburzeń genetycznych oraz obecność pierścieniowatych syderoblastów.

\section{Klasyfikacje prognostyczne}

Zespoły mielodysplastyczne stanowią grupę zróżnicowanych nowotworów wymagających zindywidualizowanego podejścia terapeutycznego. $Z$ tego powodu powstało wiele wskaźników i klasyfikacji prognostycznych pozwalających na ustalenie prawdopodobnego czasu przeżycia chorych i wybór najkorzystniejszej opcji leczenia. Przez wiele lat „Złotym standardem” pozostawał Międzynarodowy Wskaźnik Prognostyczny (IPSS, International Prognostic Scoring System) uwzględniający trzy parametry: odsetek blastów w szpiku kostnym, głębokość cytopenii wraz z liczbą linii, których ona dotyczy oraz zaburzenia cytogenetyczne. Wyodrębniono 4 grupy ryzyka - niskiego, pośredniego-1, pośredniego-2 oraz wysokiego, różniące się oczekiwanym czasem przeżycia oraz czasem do transformacji w AML (tab. 2) [12].

W kolejnych latach opracowano Zmodyfikowany Międzynarodowy Wskaźnik Prognostyczny (IPSS-R, Revised International Prognostic Scoring System) pozwalający definiować ryzyko MDS na podstawie bardziej szczegółowych wyników morfologii krwi obwodowej, odsetka blastów oraz pięciu podgrup ryzyka cytogenetycznego. Wartość według IPSS-R umożliwia zaklasyfikowanie chorych do grupy ryzyka bardzo niskiego, niskiego, pośredniego, wysokiego oraz bardzo wysokiego (tab. 3) [13].

Pacjenci cechujący się ryzykiem niskim i pośrednim-1 według IPSS oraz bardzo niskim, niskim i pośrednim według IPSS-R stanowią grupę LR-MDS. Pacjenci cechujący się ryzykiem pośrednim-2 i wysokim według IPSS oraz wysokim i bardzo wysokim według IPSS-R są zaliczani do grupy HR-MDS. Podział ten implikuje decyzje terapeutyczne.

We wcześniej stosowanym systemie prognostycznym zaproponowanym przez WHO (WPSS, WHO Prognostic Scoring System) uwzględniono ryzyko cytogenetyczne według IPSS, zależność od przetoczeń koncentratu krwinek czerwonych (kkcz) oraz podtyp MDS zgodnie $z$ ówcześnie obowiązującą klasyfikacją WHO z 2001 roku [14].

Tabela 2. Międzynarodowy Indeks Prognostyczny (IPSS) dla zespołów mielodysplastycznych (na podstawie [12])

Table 2. International Prognostic Scoring System (IPSS) of myelodysplastic syndromes (based on [12])

\begin{tabular}{|c|c|c|c|c|c|}
\hline \multirow[t]{2}{*}{ Czynnik rokowniczy } & \multicolumn{5}{|c|}{ Punktacja } \\
\hline & 0 & 0,5 & 1 & 1,5 & 2 \\
\hline Blasty w szpiku (\%) & $<5$ & $5-10$ & - & $11-20$ & $21-30$ \\
\hline Kariotyp ${ }^{1}$ & Korzystny & Pośredni & Niekorzystny & - & - \\
\hline Cytopenie $^{2}$ & $0-1$ & $2-3$ & - & - & - \\
\hline Ryzyko wg IPSS & Suma punktów & \multicolumn{2}{|c|}{$\begin{array}{l}\text { Mediana przeżycia } \\
\text { (lata) }\end{array}$} & \multicolumn{2}{|c|}{$\begin{array}{c}\text { Mediana progresji do AML } \\
(25 \% \text { grupy, lata })\end{array}$} \\
\hline Niskie & 0 & \multicolumn{2}{|c|}{5,7} & \multicolumn{2}{|c|}{9,7} \\
\hline Pośrednie-1 & $0,5-1$ & \multicolumn{2}{|c|}{3,5} & \multicolumn{2}{|c|}{3,3} \\
\hline Pośrednie-2 & $1,5-2$ & \multicolumn{2}{|c|}{1,2} & \multicolumn{2}{|c|}{1,1} \\
\hline Wysokie & $\geq 2,5$ & \multicolumn{2}{|c|}{0,4} & \multicolumn{2}{|c|}{0,2} \\
\hline
\end{tabular}

${ }^{1}$ Kariotyp - korzystny: prawidłowy, $-Y$, del(5q), del (20q); niekorzystny: złożony, aberracje chromosomu 7; pośredni: inne nieprawidłowości cytogenetyczne; ${ }^{2}$ cytopenie: stężenie hemoglobiny < $10 \mathrm{~g} / \mathrm{dl}$; liczba granulocytów < 1,8 G/l; liczba płytek krwi < $100 \mathrm{G} / \mathrm{l}$; AML (acute myeloid leukemia) — ostra białaczka szpikowa 
Tabela 3. Zmodyfikowany Międzynarodowy Indeks Prognostyczny (IPSS-R) dla zespołów mielodysplastycznych (na podstawie [13]) Table 3. Revised International Prognostic Scoring System (IPSS-R) of myelodysplastic syndromes (based on [13])

\begin{tabular}{|c|c|c|c|c|c|c|c|}
\hline \multirow{2}{*}{$\begin{array}{l}\text { Czynnik } \\
\text { prognostyczny }\end{array}$} & \multicolumn{7}{|c|}{ Punktacja } \\
\hline & 0 & 0,5 & 1 & 1,5 & 2 & 3 & 4 \\
\hline Cytogenetyka1 & Bardzo dobra & - & Dobra & - & Pośrednia & Zła & Bardzo zła \\
\hline Blasty w szpiku (\%) & $\leq 2$ & - & $3-4$ & - & $5-10$ & $>10$ & - \\
\hline Hemoglobina [g/dl] & $\geq 10,0$ & - & $8,0-9,9$ & $<8,0$ & - & - & - \\
\hline Płytki krwi [G/l] & $\geq 100$ & $50-99$ & $<50$ & - & - & - & - \\
\hline Neutrofile [G/l] & $\geq 0,8$ & $<0,8$ & - & - & - & - & - \\
\hline \multicolumn{2}{|l|}{ Ryzyko wg IPSS-R } & \multicolumn{2}{|c|}{ Suma punktów } & \multicolumn{2}{|c|}{$\begin{array}{l}\text { Mediana przeżycia } \\
\text { (lata) }\end{array}$} & \multicolumn{2}{|c|}{$\begin{array}{l}\text { Mediana progresji do } \\
\text { AML ( } 25 \% \text { grupy, lata) }\end{array}$} \\
\hline \multicolumn{2}{|l|}{ Bardzo niskie } & \multicolumn{2}{|c|}{$0-1,0$} & \multicolumn{2}{|c|}{8,8} & \multicolumn{2}{|c|}{ Nie osiągnięto } \\
\hline \multicolumn{2}{|l|}{ Niskie } & \multicolumn{2}{|c|}{$1,5-3,0$} & \multicolumn{2}{|c|}{5,3} & \multicolumn{2}{|c|}{10,8} \\
\hline \multicolumn{2}{|l|}{ Pośrednie } & \multicolumn{2}{|c|}{$3,5-4,5$} & \multicolumn{2}{|c|}{3} & \multicolumn{2}{|c|}{3,2} \\
\hline \multicolumn{2}{|l|}{ Wysokie } & \multicolumn{2}{|c|}{$5,0-6,0$} & \multicolumn{2}{|c|}{1,6} & \multicolumn{2}{|c|}{1,4} \\
\hline \multicolumn{2}{|l|}{ Bardzo wysokie } & \multicolumn{2}{|c|}{$>6,0$} & \multicolumn{2}{|c|}{0,8} & \multicolumn{2}{|c|}{0,7} \\
\hline
\end{tabular}

${ }^{1}$ Cytogenetyka - bardzo dobra: $-Y$, del(11q); dobra: kariotyp prawidłowy, del (5q), del (12p), del(20q), podwójne z del(5q); pośrednia: del(7q), +8, +19, i(17q), wszystkie inne pojedyncze lub podwójne; zła: $-7, \operatorname{inv}(3) t(3 q) /$ del(3q), podwójne $z-7 /$ del(7q), kariotyp złożony z trzema aberracjami; bardzo zła: kariotyp złożony z więcej niż trzema aberracjami; AML (acute myeloid leukemia) — ostra białaczka szpikowa

\section{Terapia}

Znaczna część pacjentów $z$ LR-MDS $z$ bezobjawowymi cytopeniami nie wymaga leczenia. Najczęściej pojawienie się objawów choroby jest spowodowane niedokrwistością, która dotyczy 80\% pacjentów z LR-MDS [15]. Należy podkreślić, że mediana wieku zachorowania na MDS wynosi około 70 lat, a starsi pacjenci są szczególnie podatni na wystąpienie objawów niedokrwistości, jak na przykład nasilenie niewydolności krążenia i choroby wieńcowej, pogorszenie funkcji poznawczych, omdlenia i upadki [16]. Przetoczenia kkcz nie zapewniają stabilnego, właściwego stężenia hemoglobiny $(\mathrm{Hb})$, a ponadto prowadzą do przeładowania żelazem i związanego $\mathrm{z}$ nim uszkodzenia narządów [17]. $Z$ tego względu podejmowane są próby stosowania różnych terapii, takich jak erytropoetyna, lenalidomid czy leki hipometylujące (HMA, hypomethylating agents). W ostatnim czasie duże nadzieje budzi włączenie do armamentarium leków stosowanych w niedokrwistości - luspaterceptu, leku o nowym mechanizmie działania, mającego zdolność blokowania ligandów receptora transformującego czynnika wzrostu beta (TGF- $\beta$, transforming growth factor beta).

\section{Erytropoetyny}

Erytropoetyny (EPO) należą do podstawowych leków stosowanych w terapii niedokrwistości u pacjentów z LR-MDS [18-21]. Ich stosowanie wiąże się z poprawą stężenia $\mathrm{Hb}$ i zmniejszeniem zapotrzebowania na przetoczenia kkcz u około $40 \%$ pacjentów, $z$ medianą czasu trwania odpowiedzi 18-24 miesiące. Fenaux i wsp. [20] opublikowali wyniki randomizowanego badania służącego ocenie skuteczności EPO alfa w porównaniu $z$ placebo w grupie 130 chorych (85 leczono EPO, 45 przyjmowało placebo) $z$ LR-MDS i ze stężeniem $\mathrm{Hb}$ nie większym niż $10 \mathrm{~g} / \mathrm{dl}, \mathrm{z}$ umiarkowaną zależnością od przetoczeń ( $\leq 4 \mathrm{j}$. kkcz/8 tyg.) lub niezależnych od przetoczeń kkcz. Odpowiedź erytroidalną (ER, erythroid response) po 24 tygodniach terapii obserwowano u 45,9\% chorych leczonych EPO w porównaniu $z \quad 4,4 \%(\mathrm{p}<0,001)$ otrzymujących placebo. W grupie otrzymującej EPO obserwowano równie $\dot{z}$ zmniejszenie liczby pacjentów wymagających przetoczeń kkcz i wydłużenie czasu do pierwszego przetoczenia w porównaniu $z$ chorymi, którym podawano placebo. Wśród pacjentów otrzymujących EPO obserwowano 4 powikłania zakrzepowe, w tym jedno (zakrzepica żył kończyny dolnej) badacze ocenili jako związane $z$ lekiem. Odsetek chorych, którzy ulegli progresji do AML, był podobny w obu grupach $(3,5 \%$ EPO vs. $4,4 \%$ placebo). W innym randomizowanym badaniu oceniano skuteczność darbepoetyny alfa w porównaniu $z$ placebo w grupie 147 chorych o podobnej charakterystyce, jak w badaniu poprzednim [21]. Częstość przetoczeń kkcz w trakcie 24 tygodni leczenia była istotnie niższa w grupie otrzymującej darbepoetynę (36,1\% vs. 59,2\%; p = 0,008). Częstość ER w grupie leczonej darbepoetyną wynosiła $14,7 \%$ po 24 tygodniach terapii i $34,7 \%$ po 48 tygodniach (po 
zwiększeniu częstotliwości podawania EPO do co 2 tygodnie u $81 \%$ pacjentów) w porównaniu z $0 \%$ wśród pacjentów otrzymujących placebo. W grupie chorych leczonych darbepoetyną nie obserwowano większej częstości powikłań zakrzepowych [21].

Wykazano, że do czynników zwiększających prawdopodobieństwo odpowiedzi na EPO należą: niższe stężenie EPO endogennej, wyższe stężenie $\mathrm{Hb}$ i mniejsze zapotrzebowanie na przetoczenia kkcz, niższe stężenie ferrytyny, niższy odsetek blastów w szpiku kostnym, niższe ryzyko według IPSS i IPSS-R [22]. U pacjentów z LR-MDS i stężeniem EPO poniżej $100 \mathrm{jm} . / 1$ prawdopodobieństwo ER wynosi 50-93\% w porównaniu z $12-58 \%$ w przypadku pacjentów z EPO ponad $100 \mathrm{jm} . / 1$. Uwzględniając jako punkt odcięcia stężenie EPO $200 \mathrm{jm} . /$, prawdopodobieństwo uzyskania ER wynosi odpowiednio 45-82\% w porównaniu z 5-53\%. U chorych, u których stężenie endogennej EPO przekracza 500 jm./l (ok. 10\% pacjentów $z$ LR-MDS), prawdopodobieństwo ER wynosi zaledwie 10-16\% [22]. Powstało wiele skal prognostycznych ułatwiających określenie prawdopodobieństwa odpowiedzi na EPO. Skala opublikowana przez Santini i wsp. [23] uwzględnia trzy parametry: stężenie EPO ponad 200 jm./l (1 vs. 0 pkt.), stopień ryzyka według IPSS-R (odpowiednio 0, 1, 2 i 3 pkt. dla ryzyka bardzo niskiego, niskiego, pośredniego i wysokiego) oraz stężenia ferrytyny powyżej $350 \mathrm{ng} / \mathrm{ml}$ ( 1 vs. 0 pkt.). U chorych $z$ sumą punktów 0, 1, 2, 3 i 4 prawdopodobieństwo odpowiedzi na EPO wynosi odpowiednio 85\%, 80\%, 64\%, 40\% i $20 \%$. Wskaźnik prognostyczny zaproponowany przez Houston i wsp. [24] uwzględnia jedynie dwa parametry: stężenie EPO poniżej $100 \mathrm{jm} . / 1$ (2 pkt.) i niskie ryzyko według IPSS (1 pkt). Prawdopodobieństwo odpowiedzi na EPO wynosi odpowiednio $81 \%, 55 \%, 30 \%$ i $17 \%$ u pacjentów $z$ liczbą punktów $3,2,1$ i 0.

Podsumowując, zarówno w wytycznych ELN (European LeukemiaNet), jak i NCCN (National Comprehensive Cancer Network) zaleca się stosowanie erytropoetyny alfa lub darbepoetyny alfa u chorych $z$ LR-MDS $z$ objawową niedokrwistością, ze stężeniem endogennej EPO nie większym niż $500 \mathrm{jm} . / 1[25,26]$. W przypadku nieskuteczności EPO do poprawy odpowiedzi może się przyczynić dołączenie do terapii czynnika tworzącego kolonie granulocytów (G-CSF, granulocyte colony-stimulating factor) $\mathrm{w}$ dawce $1-2 \mu \mathrm{g} / \mathrm{kg}$ mc. podskórnie (s.c., subcutaneous), 2-3 razy w tygodniu [27-29].

W Polsce czynniki stymulujące erytropoezę, darbepoetyna alfa i epoetyna alfa, są objęte refundacją w ramach katalogu chemioterapii we wskazaniu
MDS niskiego lub pośredniego-1 ryzyka według IPSS - bez del(5q) - u pacjentów $z$ objawową niedokrwistością.

\section{Lenalidomid}

Lenalidomid jest obecnie lekiem $z$ wyboru $\mathrm{w}$ terapii chorych $\mathrm{z}$ niedokrwistością wymagającą transfuzji kkcz w przebiegu LR-MDS z obecnością izolowanej del(5q). Leczenie immunomodulujące lenalidomidem pozwala $\mathrm{w}$ tej grupie pacjentów na szybkie uzyskanie wysokiego odsetka odpowiedzi. Na terapię odpowiada około $75 \%$ chorych, a mediana czasu do odpowiedzi wynosi tylko 4,6 tygodnia. Dodatkowo około 35\% pacjentów uzyskuje całkowitą remisję cytogenetyczną (CCR, complete cytogenetic remission). Odpowiedzi na leczenie są długotrwałe, a mediana czasu ich trwania osiagga 2-3 lata [30].

Wykazano, że lenalidomid jest skutecznym lekiem także w pozostałych podtypach MDS. W dużym międzynarodowym badaniu III fazy porównywano skuteczność lenalidomidu $z$ placebo u chorych $z$ LR-MDS bez del(5q). Do badania włączono 239 osób, spośród których większość $(78,8 \%)$ stanowiły osoby po niepowodzeniu leczenia EPO. Warto zaznaczyć, że u 70,3\% chorych wykazano obecność co najmniej $15 \%$ pierścieniowatych syderoblastów. Lenalidomid w dawce $10 \mathrm{mg}$ /dobę otrzymało łącznie 160 pacjentów. W grupie leczonej lenalidomidem $26,9 \%$ chorych uzyskało uniezależnienie od transfuzji kkcz (RBC-TI, red blood cell-transfusion independence) przez czas nie krótszy niż 8 tygodni w porównaniu $z 2,5 \% \mathrm{w}$ grupie przyjmującej placebo $(\mathrm{p}<0,001)$. Mediana czasu trwania odpowiedzi wyniosła 30,9 tygodnia, a $90 \%$ chorych uzyskało odpowiedź w pierwszych 16 tygodniach leczenia. Wyższy odsetek odpowiedzi odnotowano u chorych $z$ mniejszym zapotrzebowaniem na transfuzje kkcz oraz z niższym wyjściowym stężeniem EPO (34\% przy $\leq 500 \mathrm{jm} . / 1$ vs. $15,5 \%$ przy stężeniu $>500 \mathrm{jm} . / 1)$. Należy podkreślić, że więcej chorych leczonych wcześniej preparatami EPO uniezależniało się od przetoczeń kkcz $\mathrm{w}$ porównaniu $\mathrm{z}$ chorymi nieleczonymi EPO; $32 \%$ w porównaniu $z$ 8,6\% $(\mathrm{p}=0,006)[31]$.

W ostatnich latach przeprowadzono badania wskazujące na potencjalną korzyść $z$ zastosowania lenalidomidu $\mathrm{w}$ skojarzeniu $z$ preparatami EPO u chorych $z$ LR-MDS bez del(5q), po wcześniejszym niepowodzeniu terapii EPO. Uzasadnienie dla tego typu terapii stanowią doniesienia o mechanizmie działania lenalidomidu, który może pozwolić na ponowne uzyskanie wrażliwości 
komórek progenitorowych erytrocytów na EPO [32-34]. W jednym $z$ badań Grupy Frankofońskiej ds. MDS (GFM, Groupe Francophone des Myélodysplasies) leczenie lenalidomidem w skojarzeniu z EPO pozwalało na uzyskanie odpowiedzi u $55 \%$ chorych w porównaniu $z 36 \%$ chorych leczonych lenalidomidem w monoterapii [32]. W dużym badaniu III fazy przeprowadzonym przez GFM 39,4\% chorych leczonych lenalidomidem $\mathrm{w}$ skojarzeniu $z$ EPO uzyskało poprawę hematologiczną w zakresie erytropoezy (HI-E, hematologic improvement - erythropoietic) w porównaniu z $23,1 \%$ w grupie otrzymującej sam lenalidomid. U $24,2 \%$ chorych poddanych leczeniu skojarzonemu obserwowano RBC-TI w porównaniu z 13,8\% chorych przyjmujących sam lenalidomid. Mediana czasu trwania odpowiedzi wyniosła odpowiednio 18,1 i 15,1 miesiąca $\mathrm{w}$ grupie otrzymującej tylko lenalidomid oraz lenalidomid z EPO. Toksyczność hematologiczna i niehematologiczna były porównywalne w obu badanych grupach. Odpowiednio 50\% i 57\% chorych w grupach otrzymujących lenalidomid w monoterapii oraz łącznie $z$ EPO wymagało redukcji dawki lenalidomidu przez cały okres terapii. Neutropenia i małopłytkowość w 3. i 4. stopniu nasilenia wystąpiły u około $25 \%$ pacjentów [35]. Warto podkreślić, że trombocytopenia i niedokrwistość w trakcie leczenia lenalidomidem występują rzadziej u chorych bez del(5q) niż w MDS z del(5q). Niestety, mimo skuteczności w leczeniu LR-MDS bez del(5q), lenalidomid nie jest obecnie zarejestrowany w Europie w tym wskazaniu.

\section{Luspatercept}

Luspatercept należy do całkiem nowej klasy leków regulujących dojrzewanie późnych stadiów krwinek czerwonych w szpiku kostnym. W warunkach prawidłowych końcowy etap dojrzewania linii erytroidalnej podlega kontroli między innymi przez szlaki sygnalizacyjne związane $z$ TGF- $\beta$. U pacjentów $z$ MDS wykazano podwyższone stężenie ligandów receptora TGF- $\beta$, w tym czynnika różnicowania wzrostu 11 (GDF11, growth differentiation factor 11). Wzmożona aktywacja receptora TGF- $\beta$ prowadzi do nasilenia sygnalizacji przez białka SMAD2 i SMAD3, które hamują różnicowanie linii czerwonokrwinkowej poprzez indukcję apoptozy i zahamowanie cyklu komórkowego. Luspatercept, blokując ligandy receptora TGF- $\beta$ (m. in. GDF11), hamuje wzmożoną sygnalizację SMAD2 i SMAD3, promując tym samym prawidłowe różnicowanie i dojrzewanie krwinek czerwonych. Mechanizm działania luspaterceptu wynika $z$ jego specyficznej budowy - jest białkiem fuzyjnym złożonym ze zmodyfikowanej zewnątrzkomórkowej domeny ludzkiego receptora aktywiny (ActRIIB, activin receptor type-2B) połączonej $z$ fragmentem Fc ludzkiej immunoglobuliny G1 [36, 37].

W badaniu klinicznym II fazy PACE-MDS 63\% chorych $z$ LR-MDS leczonych luspaterceptem uzyskało HI-E, zaś $38 \%$ chorych - RBC-TI przez nie mniej niż 8 tygodni [38]. Wyższy odsetek odpowiedzi odnotowano w grupie MDS-RS. Wyższy odsetek HI-E uzyskali zarówno chorzy z obecnością mutacji $S F 3 B 1$ (77\% vs. 40\%), jak i z obecnością co najmniej $15 \%$ pierścieniowatych syderoblastów (69\% vs. 43\%) [38]. Stwierdzono istotny wpływ wyjściowego stężenia EPO na skuteczność leczenia, odsetek HI-E przy wartościach EPO poniżej 200, 200-500 i ponad $500 \mathrm{jm} . / 1$ wyniósł odpowiednio 76, 58 i 43\%. Chorzy, którzy otrzymywali wcześniej preparaty EPO i/lub lenalidomid, uzyskali podobny odsetek odpowiedzi, jak pacjenci dotychczas nieleczeni. W trakcie badania odnotowano jedynie 3 przypadki zdarzeń niepożądanych o 3 . lub wyższym stopniu nasilenia [38].

Obiecujące wyniki badania PACE-MDS stały się podstawą do zaprojektowania wieloośrodkowego, randomizowanego badania III fazy MEDALIST, w którym porównywano skuteczność leczenia luspaterceptem ze stosowaniem placebo u chorych $z$ LR-MDS [39]. Do badania zakwalifikowano łącznie 229 chorych $z$ MDS-RS, cechujących się bardzo niskim, niskim i pośrednim ryzykiem według IPSS-R, wymagających transfuzji $\mathrm{KKCz}$ wynoszących co najmniej 2 j./8 tygodni, którzy wykazywali oporność lub nietolerancję EPO. Do badania włączono również chorych dotychczas nieleczonych EPO z powodu przewidywanego braku odpowiedzi na terapię. Zdecydowana większość pacjentów otrzymywała wcześniej EPO (95\%), u $98 \%$ chorych stwierdzono oporność na leczenie, zaś u $2 \%$ terapię przerwano $z$ powodu zdarzeń niepożądanych. Kryterium wyłączenia stanowiło wcześniejsze leczenie HMA i/lub lenalidomidem [39]. Luspatercept podawano s.c. co 3 tygodnie w wyjściowej dawce $1 \mathrm{mg} / \mathrm{kg}$ mc. Pierwszorzędowym punktem końcowym było uzyskanie RBC-TI przez co najmniej 8 tygodni w pierwszych 24 tygodniach badania. Za jego kluczowy drugorzędowy cel uznano uzyskanie RBC-TI przez 12 tygodni lub dłużej w pierwszych 24 i 48 tygodniach badania. Pozostałe drugorzędowe punkty końcowe obejmowały między innymi odsetek HI-E, czas trwania odpowiedzi, średni wzrost stężenia $\mathrm{Hb}$, wpływ na progresję do AML oraz analizę bezpieczeństwa. Spośród 229 pacjentów włączonych do badania 153 otrzymywało luspatercept, a 76 placebo. Mediana 
wieku chorych wyniosła 71 lat, a większość pacjentów stanowili mężczyźni (63\%). Grupy ryzyka bardzo niskiego, niskiego i pośredniego według IPSS-R stanowily odpowiednio 10, 72 i $17 \%$ badanych. Pierwszorzędowy punk końcowy - RBC-TI przez co najmniej 8 tygodni - uzyskało $38 \%$ pacjentów leczonych luspaterceptem w porównaniu z $13 \%$ w grupie przyjmującej placebo $(\mathrm{p}<0,0001)$. $\mathrm{U} 62 \%$ pacjentów, którzy osiąnęli pierwszorzędowy punkt końcowy, stwierdzono co najmniej dwa 8-tygodniowe okresy bez konieczności transfuzji kkcz. Zdecydowana większość odpowiedzi (90\%) wystąpiła przy początkowej dawce leku (1 mg/kg mc.), a u 7\% chorych RBC-TI osiągnięto po zwiększeniu dawki leku. Brak konieczności transfuzji kkcz przez co najmniej 12 tygodni w pierwszych 24 i 48 tygodniach badania uzyskano odpowiednio u 28 i $33 \%$ pacjentów w porównaniu z 8 i $12 \%$ chorych w grupie przyjmującej placebo $(\mathrm{p}<0,001)$. Wyższy odsetek odpowiedzi uzyskano u chorych z mniejszym zapotrzebowaniem na transfuzje: w grupach wymagających poniżej $4,4-5$ oraz co najmniej 6 j. kkcz/8 tygodni odsetek RBC-TI wynosił odpowiednio 80, $37 \mathrm{i} 9 \%$.

Podobnie jak w badaniu PACE-MDS, w badaniu MEDALIST uzyskano istotny odsetek odpowiedzi $\mathrm{u}$ chorych $z$ wysokim stężeniem endogennej EPO, u których leczenie czynnikami pobudzającymi erytropoezę (ESA, erythropoiesis stimulating agents) jest mało skuteczne - w grupie $z$ wyjściowym stężeniem EPO wynoszącym 200-500 jm./1 odnotowano $40 \%$ odpowiedzi. W momencie analizy mediana czasu trwania najdłuższego RBC-TI wynosiła 30,6 miesiąca w grupie leczonej luspaterceptem, a u $14 \%$ chorych odpowiedź na leczenie trwała ponad rok. Prawie połowa chorych (46\%) kontynuowała leczenia luspaterceptem. W pierwszych 24 i 48 tygodniach leczenia HI-E wystąpiła u 53 i 59\% pacjentów otrzymujących luspatercept w porównaniu z 12 i $17 \%$ w grupie przyjmującej placebo. W ramach badania oceniono również uzyskanie RBC-TI przez co najmniej 16 tygodni w pierwszych 24 i 48 tygodniach leczenia, który stwierdzono u 19 i $28 \%$ chorych przyjmujących luspatercept i tylko u 7 i $4 \%$ w grupie przyjmującej placebo. Mediana wzrostu stężenia $\mathrm{Hb}$ u chorych uzyskujących odpowiedź wyniosła 2,55 g/dl (zakres $1-4,1 \mathrm{~g} / \mathrm{dl})$. Wzrost stężenia Hb o co najmniej $1 \mathrm{~g} / \mathrm{dl}$ odnotowano u $35 \%$ chorych po 24 tygodniach i u $41 \%$ po 48 tygodniach leczenia w grupie leczonej luspaterceptem.

Luspatercept charakteryzował się korzystnym profilem bezpieczeństwa. Zdecydowana większość odnotowanych działań niepożądanych związanych $z$ leczeniem (TEAE, treatment emergent adverse event) miała 1.-2. stopień nasilenia, a do najczęstszych należały zmęczenie (27\%), biegunka (22\%), astenia (20\%), nudności (20\%), zawroty głowy (20\%) i ból pleców (19\%) [39]. Poważne zdarzenia niepożądane (SAE, serious adverse event) i działania niepożądane w 3.-4. stopniu nasilenia odnotowano w obu grupach, u podobnego odsetka pacjentów (31 i $30 \% \mathrm{w}$ grupie otrzymującej luspatercept oraz 42 i $45 \%$ w grupie przyjmującej placebo). Działania niepożądane były powodem przerwania leczenia u $8 \%$ chorych w obu badanych grupach. Jedynie $5 \%$ chorych wymagało redukcji dawki leku $z$ powodu TEAE. Większość zdarzeń niepożądanych odnotowano w czasie pierwszych 4 kursów leczenia. W trakcie badania odnotowano po 1 przypadku progresji do HR-MDS w każdej z grup. Transformacja do AML wystapiła odpowiednio u $3(2 \%)$ i 1 (1\%) pacjentów w grupie otrzymującej luspatercept i w grupie przyjmującej placebo.

Do badania MEDALIST włączano tylko pacjentów $z$ MDS-RS ze względu na fakt, że jest to największa grupa MDS cechująca się niskim ryzykiem transformacji do AML oraz o korzystniejszym rokowaniu niż inne podtypy MDS. Dodatkowo pacjentów z MDS-RS charakteryzują częste uzależnienie od transfuzji kkcz i krótszy czas trwania odpowiedzi po terapii preparatami ESA. W trwającym badaniu klinicznym III fazy COMMANDS (\#NCT03682536) rekrutacja obejmuje szerszą grupę pacjentów $z$ LR-MDS. W tym badaniu skuteczność i bezpieczeństwo luspaterceptu są porównywane ze skutecznością i bezpieczeństwem epoetyny alfa u chorych na LR-MDS wymagających transfuzji kkcz, którzy nie byli wcześniej leczeni ESA.

W 2020 roku luspatercept (Reblozyl ${ }^{\circledR}$; Bristol-Myers Squibb, Acceleron Pharma) został zatwierdzony w Unii Europejskiej do leczenia dorosłych pacjentów $z$ MDS-RS, o bardzo niskim, niskim lub pośrednim ryzyku według IPSS-R, wymagających transfuzji kkcz, u których odpowiedź była niezadowalająca lub nie kwalifikowali się do leczenia preparatami ESA. Ponadto luspatercept ma obecnie wskazanie rejestracyjne w leczeniu niedokrwistości zależnej od transfuzji kkcz u dorosłych pacjentów $z$ beta-talasemią.

\section{Leki hipometylujące}

Azacytydyna (AZA) i decytabina (DEC) są obecnie standardem w terapii HR-MDS [40, 41]. W licznych badaniach wykazano również ich skuteczność w leczeniu chorych na LR-MDS [42-46]. Do badania Musto i wsp. [42] zakwalifikowano 74 
pacjentów (19,7\% cechujących się niskim i 80,3\% obciążonych pośrednim-1 ryzykiem wg IPSS). Terapia AZA pozwoliła na uzyskanie odsetka odpowiedzi u $45,9 \%$ chorych, w tym $10,8 \%$ - całkowitych remisji (CR, complete remission). Wyższy odsetek odpowiedzi $(51,4 \%)$ osiągnęli pacjenci, którzy otrzymali co najmniej 4 kursy leczenia. Mediana czasu trwania odpowiedzi wyniosła 6 miesięcy [42]. W badaniu Sanchez-Garcia i wsp. [43] 43,8\% chorych leczonych AZA uzyskało HI-E (w tym $31 \%$ RBC-TI) w porównaniu z 5,5\% w grupie otrzymującej najlepsze leczenie wspomagające (BSC, best supportive care $)(\mathrm{p}<0,01)$.

$\mathrm{W}$ ostatnich latach przeprowadzono metaanalizę wyników dotyczących 233 chorych $z$ LR-MDS, którzy byli leczeni AZA w ramach 7 różnych badań [47]. Najważniejsze punkty końcowe analizy obejmowały odsetek RBC-TI oraz łączny odsetek chorych odnoszących korzyści kliniczne $z$ leczenia pod postacią RBC-TI, HI-E, CR oraz odpowiedzi częściowej (PR, partial remission). U 90\% chorych nie występowała del(5q). Korzyści z leczenia AZA uzyskało $81,1 \%$ chorych, a odsetek RBC-TI wyniósł 38,9\% [47].

W badaniu II fazy przeprowadzonym przez Garcia-Menero i wsp. [44] porównano skuteczność i bezpieczeństwo DEC stosowanej s.c. według dwóch różnych schematów dawkowania u chorych na LR-MDS. Do badania włączono 67 pacjentów. Decytabinę podawano chorym s.c. w dawce $20 \mathrm{mg} / \mathrm{m}^{2}$ $\mathrm{w}$ dniach 1.-3. ( $\mathrm{n}=43$, grupa $\mathrm{A})$ lub $\mathrm{w}$ dniach 1., 8. i 15. ( $(n=22$, grupa B) co 28 dni. Całkowity odsetek odpowiedzi obejmował: całkowita remisję szpikową (mCR, marrow $C R$ ), $\mathrm{CR}, \mathrm{PR}$ oraz poprawę hematologiczną (HI, hematological improvement) i wyniósł $23 \%$ niezależnie od schematu dawkowania. Uniezależnienie od transfuzji kkcz lub koncentratu krwinek płytkowych (kkp) uzyskano u 67 i $59 \%$ chorych w grupach A i B. Większość TEAE stanowiły hematologiczne działania niepożądane; neutropenię, małopłytkowość i niedokrwistość stwierdzono odpowiednio u 31, 22 i 22\% pacjentów [44].

$\mathrm{W}$ innym randomizowanym badaniu II fazy podjęto próbę bezpośredniego porównania skuteczności obu HMA w terapii LR-MDS [45]. Do badania włączono 113 pacjentów, spośród których 40 otrzymało AZA, a 73 DEC. Odsetek CR wyniósł odpowiednio 38 i $29 \%$ w grupach leczonych AZA i DEC. W badaniu wykazano istotne wydłużenie przeżycia wolnego od zdarzeń (EFS, event-free survival) w grupie leczonej DEC (19,6 vs. 13,7 mies.; $\mathrm{p}=0,15)$. Nie odnotowano jednak istotnej różnicy w OS; odsetek rocznego OS wyniósł odpowiednio 87 i $84 \%$ w grupach leczonych DEC i AZA $(p=0,8)[45]$.
Niestety większość danych dotyczących zastosowania HMA w LR-MDS pochodzi głównie $z$ badań retrospektywnych, przeprowadzonych w małych grupach chorych. Ponadto dotychczas opublikowane wyniki badań wskazują na duże zróżnicowanie odsetków odpowiedzi. Konieczne jest przeprowadzenie dodatkowych dużych badań randomizowanych. W jedynym dotychczas przeprowadzonym badaniu prospektywnym zastosowanie AZA pozwoliło na uzyskanie RBC-TI u 20\% pacjentów $(\mathrm{n}=6) \mathrm{z}$ LR-MDS po niepowodzeniu terapii ESA. Mediana czasu trwania odpowiedzi nie przekroczyła 6 miesięcy [47].

Mimo swojej skuteczności żaden $z$ HMA nie jest obecnie zarejestrowany w Europie do terapii LR-MDS. Azacytydyna jest aktualnie zarejestrowana w leczeniu MDS o niższym ryzyku tylko w Stanach Zjednoczonych i Japonii.

\section{Terapia małopłytkowości}

Małopłytkowość występuje u około połowy chorych na MDS [2]. U podłoża jej patogenezy leży zmniejszone wytwarzanie płytek wskutek deregulacji szlaku trombopoetyny (TPO) i apoptozy dysplastycznych megakariocytów w szpiku, jak również skrócony czas przeżycia płytek we krwi obwodowej [48, 49]. Przetoczenia kkp są zalecane w przypadku obniżenia liczby płytek krwi poniżej 10 G/l lub przy wyższej ich liczbie, jeśli występują objawy skazy krwotocznej małopłytkowej lub aktywne krwawienie. Jednak powtarzane transfuzje kkp mogą prowadzić do wielu powikłań, jak na przykład odczyny poprzetoczeniowe czy alloimmunizacja.

Agoniści receptora TPO - romiplostin i eltrombopag - są zarejestrowane w leczeniu pierwotnej małopłytkowości immunologicznej. W ostatnich latach leki te są również badane w LR-MDS. W badaniu Fenaux i wsp. [50] obejmującym 60 chorych $z$ MDS niskiego i pośredniego-1 ryzyka według IPSS $z$ małopłytkowością poniżej $50 \mathrm{G} / 1$ stosowano romiplostym. Odpowiedź płytkową wykazano u $57 \%$ chorych $z$ medianą czasu trwania 33 tygodnie [50]. We wcześniejszych badaniach w LR-MDS uniezależnienie od przetoczeń obserwowano u 46-61\% chorych [51, 52]. Działania niepożądane związane $z$ lekiem wystąpiły u $11 \%$ chorych [51]. Czynnikami determinującymi odpowiedź na romiplostym były wyjściowe stężenie endogennej TPO poniżej $500 \mathrm{pg} / \mathrm{ml}$ oraz liczba transfuzji kkp w ostatnim roku mniejsza niż 6 [53]. Skuteczność eltrombopagu oceniano w badaniu II fazy EQoL-MDS, do którego włączono 90 chorych na LR-MDS z liczbą płytek krwi poniżej $30 \mathrm{G} / 1$ 
poddanych randomizacji do grupy przyjmującej placebo albo leczonej eltrombopagiem w różnych dawkach [54]. Po medianie czasu obserwacji wynoszącej 11 miesięcy $47 \%$ chorych $z$ grupy leczonej eltormbopagiem osiągnęło odpowiedź płytkową w porównaniu $z 3 \%$ chorych $z$ grupy przyjmującej placebo (95-proc. przedział ufności [CI, confidence interval]: 3.5-211,9; $\mathrm{p}=0,0017)$. Eltrombopag nie zwiększał ryzyka transformacji do AML (12 vs. 16\% $\mathrm{w}$ grupie przyjmującej placebo; $\mathrm{p}=0,0053)$ [54].

$\mathrm{W}$ badaniach in vitro leki $\mathrm{z}$ grupy agonistów receptora TPO powodowały zwiększenie odsetka blastów, co budziło obawy zwiększenia ryzyka transformacji do AML in vivo [55]. Jednak w kilkuletnich obserwacjach klinicznych ani w metaanalizach wyników badań klinicznych nie potwierdzono większej częstości transformacji do AML [50, 56, 57].

Wysokie odsetki odpowiedzi płytkowych $\mathrm{w}$ badaniach $\mathrm{z}$ zastosowaniem agonistów receptorów TPO w monoterapii leżały u podłoża hipotezy, że leki te stosowane w kombinacji z HMA lub lenalidomidem mogą zmniejszać ich toksyczność hematologiczną. W badaniu II fazy obejmującym chorych $z$ MDS niskiego i pośredniego ryzyka według IPSS stosowano romiplostym w połączeniu z AZA [58]. U chorych, u których stosowano terapię skojarzoną, liczba płytek krwi była wyższa niż u chorych leczonych AZA [58]. W innym badaniu dołączenie romiplostymu do DEC istotnie ograniczało liczbę krwawień (27 vs. $43 \%$ w grupie przyjmującej placebo) oraz zapotrzebowanie na transfuzje kkp (odpowiednio 47 i 57\%) w porównaniu $z$ grupą przyjmującą placebo [59].

Podsumowując, mimo korzystnych wyników badań, leki będące agonistami receptora TPO nie są obecnie zarejestrowane w leczeniu MDS ani $\mathrm{w}$ terapii skojarzonej, ani w monoterapii.

\section{Terapia neutropenii}

Neutropenia występuje u 15-20\% chorych na MDS niższego ryzyka, a nawracające infekcje w jej przebiegu są przyczyną około $30 \%$ zgonów $\mathrm{w}$ tej grupie chorych $[60,61]$. Wykazano, że leczenie immunosupresyjne, immunomodulujące lub hipometylujące, a także przeładowanie żelazem zwiększają ryzyko infekcji [60]. W tej grupie chorych można rozważyć profilaktyczne stosowanie antybiotyków. Według zaleceń ekspertów $\mathrm{u}$ chorych $\mathrm{z}$ neutropenią pozostających jedynie pod obserwacją nie ma uzasadnienia antybiotykoterapia profilaktyczna ani stosowanie G-CSF $[60,62]$. W przypadku gorączki neutropenicznej wskazane jest pilne wdrożenie szerokowidmowej antybiotykoterapii i G-CSF.

\section{Terapia immunosupresyjna}

U części pacjentów $z$ cytopeniami w przebiegu LR-MDS skuteczne może się okazać leczenie immunosupresyjne $z$ zastosowaniem immunoglobuliny antytymocytarnej (ATG, anti-tymocyte globulins) i cyklosporyny A (CsA). Podstawa takiego typu terapii to założenie, że przyczyną cytopenii jest nadmierna aktywność limfocytów T prowadząca do supresji hematopoezy, podobnie jak w przypadku niedokrwistości aplastycznej [63].

Większość badań oceniających skuteczność terapii z zastosowaniem ATG w MDS obejmowała małe grupy chorych lub miała charakter retrospektywny. $\mathrm{Na}$ ich podstawie wyróżniono wiele czynników, których obecność zwiększa prawdopodobieństwo odpowiedzi na terapię immunosupresyjną. Należą do nich: młodszy wiek pacjentów, hipoplastyczny szpik kostny, prawidłowy kariotyp (lub z obecnością trisomii chromosomu 8), obecność allela HLA-DR15, obecność klonu nocnej napadowej hemoglobinurii (PNH, paroxysmal nocturnal hemoglobinuria), krótszy czas zależności od przetoczeń, nieobecność pierścieniowych syderoblastów (lub mutacji SF3B1) [18, 19, 64-68].

$\mathrm{W}$ randomizowanym badaniu III fazy 45 pacjentów (71\% cechujących się ryzykiem niskim i pośrednim-1 wg IPSS) otrzymało terapię ATG + CsA i 43 chorych $(76 \%$ cechujących się ryzykiem niskim i pośrednim-1) - BSC [66]. W grupie leczonej ATG + CsA podtypy: oporna niedokrwistość (RA, refractory anemia), oporna niedokrwistość z obecnością pierścieniowatych sideroblastów (RARS, refractory anemia with ring sideroblasts), oporna niedokrwistość $z$ nadmiarem blastów (RAEB-1, refractory anemia with excess of blasts) i RAEB-2 oraz hipoplastyczny MDS stwierdzono odpowiednio u 21, 6, 9, 0 i 9 pacjentów, natomiast w grupie poddanej BSC u 18, 8, 11, 2 i 4 chorych. Końską ATG stosowano w dawce $15 \mathrm{mg} / \mathrm{kg} \mathrm{mc}$. przez 5 dni, natomiast CsA doustnie przez 180 dni. Po 6 miesiącach u 29\% pacjentów leczonych ATG + CsA obserwowano odpowiedź hematologiczną w porównaniu $z$ 9\% chorych w grupie poddanej BSC $(\mathrm{p}=0,0156)$. Pacjentów $z$ niższym odsetkiem blastów i hipoplastycznym szpikiem charakteryzowało większe prawdopodobieństwo odpowiedzi. Przeżycie wolne od transformacji (TFS, transformation free survival) po 2 latach nie różniło się istotnie w obu grupach i wynosiło $46 \%$ w grupie leczonej ATG + CsA i 55\% w grupie poddanej BSC $(\mathrm{p}=0,730)$. Całkowity czas przeżycia wyniósł odpowiednio 49\% (95\% CI: 31-66\%) i $63 \%$ (95\% CI: 42-78\%), w grupie leczonej ATG + CsA i w grupie poddanej BSC $(p=0,828)$ [66]. Sloand 
i wsp. [67] retrospektywnie ocenili skuteczność leczenia immunosupresyjnego $\mathrm{z}$ zastosowaniem ATG, CsA lub ATG + CsA łącznie w grupie 129 pacjentów $z$ MDS. U 39 chorych (30\%) obserwowano częściową lub całkowitą odpowiedź hematologiczną, w tym u 18 (24\%) spośród 74 pacjentów leczonych ATG, u 20 (48\%) spośród 42 leczonych ATG + CsA i u $1(8 \%)$ z 13 pacjentów leczonych tylko CsA. Analiza wielowariancyjna wykazała, że czynnikami korzystnie wpływającymi na odpowiedź są młodszy wiek, obecność HLA-DR15, ryzyko niskie i pośrednie według IPSS oraz łączne stosowanie ATG + CsA [67].

Stahl i wsp. [68] przeprowadzili retrospektywną analizę skuteczności terapii immunosupresyjnej w dużej grupie 207 chorych na MDS z 15 ośrodków w Stanach Zjednoczonych i Europie. Według skali IPSS odpowiednio 22, 69 i $9 \%$ pacjentów należało do grupy ryzyka niskiego, pośredniego-1 oraz pośredniego-2 i wysokiego. Jako leczenie immunosupresyjne $76 \%$ pacjentów otrzymało ATG (samodzielnie lub lącznie $z \mathrm{CsA}$, prednizonem lub takrolimusem), $13 \%$ CsA i $4 \%$ takrolimus jako jedyną terapię. U $62 \%$ chorych zastosowano króliczą ATG, natomiast u 38\% - końską. Odpowiedź obserwowano u 48,8\% pacjentów, w tym u $11,2 \% \mathrm{CR}$, u $5,6 \% \mathrm{PR}$, a u $32 \%$ HI. U $30 \%$ pacjentów zależnych od transfuzji obserwowano uniezależnienie od przetoczeń kkcz. Dla całej grupy pacjentów mediana OS od włączenia terapii immunosupresyjnej wynosiła 47,4 miesiąca, przy czym u chorych, u których obserwowano odpowiedź (CR/PR/HI), mediana OS nie została osiągnięta, a u pozostałych chorych wyniosła 27,7 miesiąca $(\mathrm{p}=0,0009)$. Podobnie u pacjentów, którzy uniezależnili się od przetoczeń, obserwowano dłuższe czasy przeżycia (mediana OS nieosiągnięta $v s$. 26,6 miesiąca; $\mathrm{p}=0,0002)$. W analizie jednowariancyjnej jedynym zidentyfikowanym czynnikiem wpływającym na prawdopodobieństwo odpowiedzi była obecność mutacji $S F 3 B 1$ (istotność niepotwierdzona w analizie wielowariancyjnej). $\mathrm{Na}-$ tomiast wśród czynników wpływających na prawdopodobieństwo uniezależnienia od przetoczeń za istotne na podstawie analizy jednowariancyjnej uznano: hipoplastyczny szpik kostny, zastosowanie terapii immunosupresyjnej jako leczenia pierwszej linii, terapię końską ATG (vs. królicza), terapię ATG + CsA (vs. inne kombinacje leków). W analizie wielowariancyjnej istotność zachował tylko jeden czynnik - hipoplastyczny szpik kostny [68].

Podsumowując, autorzy rekomendacji europejskich zalecają zastosowanie leczenia immunosupresyjnego (ATG + CsA) u pacjentów $z$ LR-MDS i $z$ niedokrwistością wymagającą przetoczeń i dodatkowo spełniających takie warunki, jak: wiek
60 lat lub mniej, hipoplastyczny szpik, nie więcej niż 5\% blastów, prawidłowy kariotyp [25]. Z kolei NCCN rekomenduje terapię immunosupresyjną u pacjentów z LR-MDS i z objawową małoplytkowością i/lub neutropenią spełniających podobne warunki, jak w rekomendacjach ELN [26].

\section{Leczenie chelatujące}

Szacuje się, że około $50 \%$ chorych na LR-MDS wymaga przetoczenia $\mathrm{kkcz} \mathrm{w}$ przebiegu choroby [69]. Zależność od przetoczeń jest złym czynnikiem rokowniczym $w$ przebiegu MDS, głównie $z$ powodu późnych powikłań licznych transfuzji - przeładowania żelazem oraz allommunizacji [70, 71]. Ładunek żelaza dostarczanego wraz $\mathrm{z}$ transfuzją przewyższa możliwości związania go przez transferrynę i w postaci wolnej we krwi prowadzi do powstawania wolnych rodników tlenowych, które w konsekwencji prowadzą do uszkodzenia między innymi serca, wątroby, trzustki czy upośledzenia hematopoezy [70, 72-74]. Jedną z metod zapobiegających szkodliwemu przeładowaniu żelazem jest stosowanie leków chelatujących. Przedstawicielami tej grupy leków są deferazyroks i deferypron (formy doustne) oraz deferoksamina (forma pozajelitowa). Deferoksaminę stosuje się w dawce $25-40 \mathrm{mg} / \mathrm{kg} \mathrm{mc}$. pozajelitowo. Istotnymi ograniczeniami jej stosowania są konieczność podawania długotrwałych, 10-12-godzinnych wlewów s.c. przez co najmniej 5 dni/tydzień oraz toksyczność. Najczęstsze działania niepożądane to reakcje miejscowe, uszkodzenie wzroku i słuchu oraz powikłania neurologiczne. Deferypron był pierwszym lekiem chelatującym w postaci doustnej. Jest stosowany w dawce 75$-100 \mathrm{mg} / \mathrm{kg} \mathrm{mc}$. w 3 dawkach podzielonych. Istotnym ograniczeniem jego stosowania w MDS pozostaje często (do 8,5\% chorych) występująca neutropenia, czasami agranulocytoza. W związku $z$ tym deferypron zarejestrowano tylko do terapii chelatującej u chorych na talasemię.

Deferazyroks jest zarejestrowany w Europie do leczenia przeładowania żelazem w przypadku braku możliwości leczenia deferoksamną lub jej nieskuteczności. Lek stosuje się w postaci doustnej, w dawce $20-30 \mathrm{mg} / \mathrm{kg} \mathrm{mc}$. raz/dobę. Najczęstszymi działaniami niepożądanymi są zaburzenia ze strony przewodu pokarmowego - wymioty, biegunki, ale również zaparcia [75]. Innym działaniem toksycznym ograniczającym jego stosowanie jest wzrost stężenia kreatyniny w surowicy, dlatego lek można podawać wyłącznie chorym $z$ wyjściowo prawidłową czynnością nerek [75]. W Polsce lek jest dostępny w ramach programu lekowego wyłącznie dla osób do 18. roku życia. 
Oprócz działania zmniejszającego przeładowanie $\dot{z}$ elazem, w wielu badaniach wykazano, $\dot{z} \mathrm{e}$ skuteczna terapia chelatująca wpływa również na zmniejszenie częstości transfuzji kkcz. W badaniu Jensena i wsp. [76] 11 chorych na MDS, zależnych od przetoczeń, otrzymywało deferoksaminę. Pięciu chorych uniezależniło się od przetoczeń. Obserwowano również wzrost liczby płytek krwi oraz neutrofilów. Należy jednak podkreślić, że czas do maksymalnej odpowiedzi czerwonokrwinkowej wynosił 1,5 roku [76]. Biorąc pod uwagę sposób podawania leku, uzyskanie istotnej poprawy może być trudne w codziennej praktyce klinicznej. Poprawę hematologiczną obserwowano również w badaniach $\mathrm{z}$ zastosowaniem deferazyroksu. W badaniu EPIC uczestniczyło łącznie 1744 chorych, w tym 341 chorych na MDS zależnych od przetoczeń kkcz [75]. Po rocznej terapii deferazyroksem odpowiedź czerwonokrwinkową uzyskało $26,6 \%$ chorych, zaś płytkową i neutrofilową - 14 i 19,6\% chorych. Mediana czasu do uzyskania odpowiedzi wynosiła 169 dni (zakres 84-382 dni) [75]. W innym badaniu obejmującym 55 chorych na LR-MDS leczonych przez 2 lata deferazyroksem poprawę hematologiczną wykazano u 16 (29\%) chorych [77].

W wielu prospektywnych i retrospektywnych badaniach dowiedziono, że terapia chelatująca żelazo wydłuża przeżycie chorych na MDS niższego ryzyka zależnych od przetoczeń [78-80]. W retrospektywnym badaniu Remacha i wsp. [79] analizowano 263 chorych na LR-MDS zależnych od transfuzji, którzy otrzymali co najmniej $10 \mathrm{j}$. kkcz. Chorzy przez minimum 6 miesięcy otrzymywali leczenie chelatujące. Najczęściej stosowanym lekiem był deferazyroks. U chorych poddanych terapii chelatującej OS było istotnie dłuższe niż w grupie nieleczonej chelatorami [79]. W kanadyjskiej analizie chorych $z$ rejestru MDS analizowano OS 239 chorych na LR-MDS od czasu otrzymania pierwszej transfuzji kkcz [78]. Spośród tej grupy 83 chorych otrzymywało leczenie chelatujące (deferazyroks 75,9\% chorych, deferoksaminę 43\%, leczenie skojarzone 7\%). Chorzy poddani terapii chelatującej nie różnili się istotnie pod względem stanu sprawności czy wskaźnika chorób wspó1istniejących od grupy tak nieleczonej. Mediana OS była dłuższa w grupie leczonych chelatorami $\mathrm{w}$ porównaniu $\mathrm{z}$ grupą kontrolną (5,2 vs. 2,1 roku; $\mathrm{p}<0,0002)$. W analizie wielowariancyjnej brak terapii chelatującej był czynnikiem predykcyjnym krótszego OS. Różnice w OS wykazano również $\mathrm{w}$ analizie typu par pod względem wieku, stanu sprawności oraz R-IPSS [78]. W metaanalizie Mainous i wsp. [81] analizowano badania retrospek- tywne dotyczące terapii chelatującej. Wyszukiwano oryginalne artykuły $z$ pełnym opisem szczegółów badania, $z$ obecnością grupy kontrolnej, która nie otrzymywała leczenia chelatującego oraz takie, w których oceniano OS. Spośród 1234 doniesień 8 spełniało wymienione wyżej kryteria. Nie zidentyfikowano badań randomizowanych; wszystkie prace miały charakter badań obserwacyjnych. Łącznie analizą objęto 1562 chorych. Metaanaliza wykazała, że zastosowanie terapii chelatującej istotnie wydłuża życie pacjentów (mediana różnicy OS 61,2 mies.) [81]. Oceniając wyniki tej metaanalizy, należy wziąć pod uwagę fakt, że dotyczyła ona tylko badań obserwacyjnych, w których do terapii chelatującej mogli być kwalifikowani chorzy lepiej rokujący, co mogło wpłynąć na wyniki.

$Z$ kolei w innych badaniach nie wykazano wpływu terapii chelatującej na OS. W badaniu II fazy TELESTO (NCT00940602) porównywano EFS u chorych $z$ MDS niższego ryzyka leczonych deferazyroksem i przyjmujących placebo [82]. Wykazano, że stosowanie deferazyroksu wydłuża EFS (1440 dni [95\% CI: 1167-1559]) w porównaniu $z$ placebo (1091 dni [95\% CI: 820-1348]; $p=0,015$ ), jednak wpływa na OS. Przeżycie wolne od zdarzeń zdefiniowano jako wystąpienie toksyczności sercowej lub wątrobowej niezakończonej zgonem, transformację do AML lub zgon [82]. Inni badacze podkreślają, że profil działań niepożądanych leków chelatujących (niewydolność nerek oraz krwawienie $z$ przewodu pokarmowego $\mathrm{w}$ przypadku deferazyroksu oraz agranulocytoza $\mathrm{w}$ przypadku deferypronu) ogranicza ich stosowanie w przypadku małopłytkowości i neutropenii [62]. Dotychczas nie ma badań, których wyniki jednoznacznie określałyby rolę terapii chelatującej w LR-MDS. Jednak według zaleceń ELN oraz NCCN należy rozważyć terapię deferoksaminą lub deferazyroksem $\mathrm{u}$ chorych po przetoczeniu $20 \mathrm{j}$. kkcz przy stężeniu ferrytyny ponad $2500 \mathrm{ng} / \mathrm{ml} \mathrm{lub}$ po przetoczeniu $25 \mathrm{j}$. kkcz przy stężeniu ferrytyny powyżej $1000 \mathrm{ng} / \mathrm{ml}[25,62]$. Biorąc pod uwagę brak jednoznacznych danych dotyczących stosowania terapii chelatujących, postępowaniem profilaktycznym w przypadku przeładowania żelazem jest ograniczenie liczby przetoczeń do sytuacji klinicznie koniecznych.

\section{Nowe kierunki terapii LR-MDS}

\section{Sotatercept}

Sotatercept należy do grupy leków regulujących dojrzewanie linii czerwonokrwinkowej poprzez blokowanie ligandów receptora TGF- $\beta$. W odróżnieniu od luspaterceptu, w jego skład 
wchodzi zewnątrzkomórkowa domena receptora ActRIIA [36]. W badaniu II fazy skuteczność i bezpieczeństwo sotaterceptu oceniono u pacjentów z MDS niskiego i pośredniego-1 ryzyka według IPSS wymagających transfuzji kkcz. Do badania włączono chorych po nieskuteczności terapii EPO lub $z$ przewidywanym brakiem odpowiedzi na powyższą terapię. Około połowa chorych otrzymywała wcześniej HMA lub lenalidomid. Spośród ocenionych 74 pacjentów HI-E osiągnęło 49\%, $\mathrm{w}$ tym $47 \% \mathrm{w}$ grupie o wysokim zapotrzebowaniu na transfuzje. U 59\% chorych $z$ MDS-RS oraz u $22 \%$ spośród pozostałych pacjentów stwierdzono HI-E. Leczenie było dobrze tolerowane. Najczęstsze zdarzenia niepożądane obejmowały zmęczenie, obrzęki obwodowe, biegunkę i nudności; TEAE o 3 . i 4 . stopniu nasilenia wystąpiły u $34 \%$ pacjentów [83].

\section{Imetelstat}

Imetelstat jest inhibitorem telomerazy wykazującym wysoką skuteczność w terapii nowotworów mieloidalnych. W badaniu II fazy IMerge imetelstat podawano 38 pacjentom $z$ LR-MDS, zależnym od transfuzji kkcz, po nieskuteczności terapii EPO [84]. Terapia pozwoliła na uzyskanie wysokiego odsetka długotrwałych odpowiedzi; odpowiednio u 42 i $68 \%$ pacjentów osiągnięto RBC-TI i HI-E o medianie czasu trwania 20 i 21 miesięcy. U 75\% chorych, którzy uzyskali RBC-TI, stwierdzono wzrost stężenia $\mathrm{Hb}$ o $3 \mathrm{~g} / \mathrm{dl}$ wobec wartości wyjściowej, a $29 \%$ pacjentów nie wymagało transfuzji przez ponad rok po uzyskaniu odpowiedzi. Podobną skuteczność leczenia uzyskano u wszystkich chorych, niezależnie od wyjściowego stężenia EPO, zapotrzebowania na kkcz czy podtypu MDS. Należy podkreślić, że w trakcie leczenia imetelstatem $24 \%$ pacjentów osiągnęło $\mathrm{CR} / \mathrm{mCR}$. Większość TEAE stanowiły cytopenie: małopłytkowość i neutropenię stwierdzono odpowiednio u 66 i 58\% pacjentów [84].

\section{Nowe leki hipometylujące}

Lek o nazwie CC-486 jest doustną postacią AZA. Terapia doustna jest lepiej tolerowana i nie wymaga hospitalizacji pacjenta, co pozwala na przedłużenie dawkowania leku. Zwiększone narażenie komórek nowotworowych na AZA powoduje wydłużenie działania hipometylującego, maksymalizując efekt terapeutyczny. Dodatkowo doustna podaż leku jest wygodniejsza dla chorych i pozwala uniknąc miejscowych działań niepożądanych po wstrzyknięciach s.c. W badaniu I fazy CC-486 podawano 28 chorym z LR-MDS przez 14 lub 21 dni w schemacie 28-dniowym. Uzyskano całkowity odsetek odpowiedzi u $38 \%$ pacjentów, w tym $36 \%$ w 14-dniowym i $41 \%$ w 21 -dniowym schemacie leczenia [85]. W obu grupach uzyskano podobny odsetek RBC-TI (31 i 38\%). Większość odpowiedzi $(71 \%)$ uzyskano w ciągu pierwszych 3 cykli leczenia. Leczenie było dobrze tolerowane; większość działań niepożądanych stanowiły zaburzenia żołądkowo-jelitowe o umiarkowanym nasileniu. Zdarzenia niepożądane o 3.-4. stopniu nasilenia wystąpiły u $45 \%$ pacjentów [85]. W badaniu III fazy skuteczność i bezpieczeństwo CC-486 porównywano $z$ placebo $u$ chorych $z$ LR-MDS wymagających transfuzji kkcz lub kkp [86]. W grupie otrzymującej badany lek uzyskano znacznie wyższy odsetek RBC-TI niż w grupie przyjmującej placebo (31 vs. $11 \% ; p=0,0002)$. Mediana czasu trwania RBC-TI $\mathrm{w}$ grupie leczonej CC-486 wyniosła 11 miesięcy w porównaniu z 5 miesiącami w grupie przyjmującej placebo. Chorzy leczeni CC-486 uzyskali również istotnie statystycznie wyższy odsetek poprawy hematologicznej w układzie płytkowym (HI-P, hematologic improvement - platelet) niż w grupie przyjmującej placebo $-24 \mathrm{w}$ porównaniu $z 7 \%$; $\mathrm{p}=0,0003$. Uniezależnienie od transfuzji preparatów kkp (PLT-TI, platelet transfusion independence) uzyskano u podobnej liczby pacjentów w obu badanych grupach, jednak mediana czasu trwania PLT-TI była znacznie dłuższa w grupie leczonej CC-486 (12,1 vs. 4,4 mies.). Więcej TEAE o 3.-4. stopniu nasilenia stwierdzono u chorych leczonych CC-486 niż u pacjentów otrzymujących placebo (90 vs. 73\%). Badanie przerwano ze względu na stwierdzoną większa liczbę zgonów w grupie leczonej CC-486 $(\mathrm{n}=16)$ w porównaniu z przyjmującymi placebo $(n=6)$ w pierwszych 56 dniach badania. Przyczyną większości zgonów były infekcje [86].

Cząsteczka ASTX727 (Inqovi ${ }^{\circledR}$, Astex Pharmaceuticals, Inc.) stanowi połączenie decytabiny Z cedazurydyną będącą inhibitorem deaminazy cytydyny (CDA, cytidine deaminase). Nadekspresja enzymu CDA jest jednym $z$ mechanizmów oporności na HMA. Zablokowanie działania CDA pozwala na utrzymanie wyższego stężenia DEC w komórkach i uzyskanie lepszego efektu terapeutycznego [87]. Skuteczność Inqovi ${ }^{\circledR}$ wykazano w dwóch badaniach II fazy (ASTX727-01-B i ASTX727-02) obejmujących odpowiednio 80 i 133 chorych z MDS o pośrednim-1, pośrednim-2 i wysokim ryzyku według IPSS oraz z przewlekłą białaczką mielomonocytową (CMML, chronic myelomonocytic leukemia). W obu badaniach CR uzyskało około $20 \%$ pacjentów i około połowa chorych uniezależniła się od transfuzji kkcz lub kkp. Mediana czasu od- 
powiedzi wyniosła odpowiednio 8,7 i 7,5 miesiąca. Tolerancja i bezpieczeństwo leczenia preparatem Inqovi ${ }^{\circledR}$ były porównywalne $z$ tolerancją i bezpieczeństwem stosowania decytabiny podawanej we wlewie dożylnym [87]. W lipcu 2020 roku preparat Inqovi ${ }^{\circledR}$ zarejestrowano w Stanach Zjednoczonych do leczenia MDS o ryzyku pośrednim-1, pośrednim-2 i wysokim według IPSS oraz do leczenia CMML. Rejestracja objęła następujące podtypy MDS według klasyfikacji FAB (French-American-British): RA, RARS oraz RAEB. Trwa badanie \#NCT03502668 nad zastosowaniem cząsteczki ASTX727 u chorych z LR-MDS.

\section{Piśmiennictwo}

1. Arber DA, Orazi A, Hasserjian R, et al. The 2016 revision to the World Health Organization classification of myeloid neoplasms and acute leukemia. Blood. 2016; 127(20): 2391-2405, doi: 10.1182/blood-2016-03-643544, indexed in Pubmed: 27069254.

2. Platzbecker U. Treatment of MDS. Blood. 2019; 133(10): 1096-1107, doi: 10.1182/blood-2018-10-844696, indexed in Pubmed: 30670446.

3. Steensma DP. Myelodysplastic syndromes current treatment algorithm 2018. Blood Cancer J. 2018; 8(5): 47, doi: 10.1038/ /s41408-018-0085-4, indexed in Pubmed: 29795386.

4. Valent P, Orazi A, Steensma DP, et al. Proposed minimal diagnostic criteria for myelodysplastic syndromes (MDS) and potential pre-MDS conditions. Oncotarget. 2017; 8(43): 73483-73500, doi: 10.18632/oncotarget.19008, indexed in Pubmed: 29088721.

5. Solé F, Espinet B, Sanz GF, et al. Incidence, characterization and prognostic significance of chromosomal abnormalities in $640 \mathrm{pa}-$ tients with primary myelodysplastic syndromes. Grupo Cooperativo Español de Citogenética Hematológica. Br J Haematol. 2000; 108(2): 346-356, doi: 10.1046/j.1365-2141.2000.01868.x, indexed in Pubmed: 10691865.

6. Visconte V, Tiu RV, Rogers HJ. Pathogenesis of myelodysplastic syndromes: an overview of molecular and non-molecular aspects of the disease. Blood Res. 2014; 49(4): 216-227, doi: 10.5045/ /br.2014.49.4.216, indexed in Pubmed: 25548754.

7. Le Beau MM, Albain KS, Larson RA, et al. Clinical and cytogenetic correlations in 63 patients with therapy-related myelodysplastic syndromes and acute nonlymphocytic leukemia: further evidence for characteristic abnormalities of chromosomes no. 5 and 7 . J Clin Oncol. 1986; 4(3): 325-345, doi: 10.1200/JCO.1986.4.3.325, indexed in Pubmed: 3950675.

8. Hosono N. Genetic abnormalities and pathophysiology of MDS. Int J Clin Oncol. 2019; 24(8): 885-892, doi: 10.1007/s10147-01901462-6, indexed in Pubmed: 31093808.

9. Mossner M, Jann JC, Nowak D, et al. Prevalence, clonal dynamics and clinical impact of TP53 mutations in patients with myelodysplastic syndrome with isolated deletion ( $5 q$ ) treated with lenalidomide: results from a prospective multicenter study of the german MDS study group (GMDS). Leukemia. 2016; 30(9): 1956-1959, doi: 10.1038/leu.2016.111, indexed in Pubmed: 27133825.

10. DiNardo CD, Watts J, Stein E, et al. Ivosidenib (AG-120) induced durable remissions and transfusion independence in patients with IDH1-mutant relapsed or refractory myelodysplastic syndrome: results from a phase 1 dose escalation and expan- sion study. Blood. 2018; 132(Suppl 1): 1812-1812, doi: 10.1182/ /blood-2018-99-111264.

11. Richard-Carpentier G, DeZern A, Takahashi K, et al. Preliminary results from the phase II study of the IDH2-inhibitor enasidenib in patients with high-risk IDH2-mutated myelodysplastic syndromes (MDS). Blood. 2019; 134(Suppl_1): 678-678, doi: 10.1182/ /blood-2019-130501.

12. Greenberg P, Cox C, LeBeau M, et al. International Scoring System for evaluating prognosis in myelodysplastic syndromes. Blood. 1997; 89(6): 2079-2088, doi: 10.1182/blood.v89.6.2079.

13. Greenberg PL, Tuechler H, Schanz J, et al. Revised international prognostic scoring system for myelodysplastic syndromes. Blood. 2012; 120(12): 2454-2465, doi: 10.1182/blood-2012-03-420489, indexed in Pubmed: 22740453.

14. Malcovati L, Porta MG, Pascutto C, et al. Prognostic factors and life expectancy in myelodysplastic syndromes classified according to WHO criteria: a basis for clinical decision making. J Clin Oncol. 2005; 23(30): 7594-7603, doi: 10.1200/JCO.2005.01.7038, indexed in Pubmed: 16186598.

15. Moreno Berggren D, Folkvaljon Y, Engvall M, et al. Prognostic scoring systems for myelodysplastic syndromes (MDS) in a population-based setting: a report from the Swedish MDS register. $\mathrm{Br}$ J Haematol. 2018; 181(5): 614-627, doi: 10.1111/bjh.15243, indexed in Pubmed: 29707769.

16. Neukirchen J, Schoonen WM, Strupp C, et al. Incidence and prevalence of myelodysplastic syndromes: data from the Düsseldorf MDS-registry. Leuk Res. 2011; 35(12): 1591-1596, doi: 10.1016/j. leukres.2011.06.001, indexed in Pubmed: 21708407.

17. Jaeger M, Aul C, Söhngen D, et al. [Secondary hemochromatosis in polytransfused patients with myelodysplastic syndromes] [Article in German]. Beitr Infusionsther. 1992; 30: 464-468, indexed in Pubmed: 1284762.

18. Fenaux P, Platzbecker U, Ades L. How we manage adults with myelodysplastic syndrome. Br J Haematol. 2020; 189(6): 1016-1027, doi: 10.1111/bjh.16206, indexed in Pubmed: 31568568.

19. Hellström-Lindberg E, Tobiasson M, Greenberg P. Myelodysplastic syndromes: moving towards personalized management. Haematologica. 2020; 105(7): 1765-1779, doi: 10.3324/haematol.2020.248955, indexed in Pubmed: 32439724.

20. Fenaux P, Santini V, Spiriti MA, et al. A phase 3 randomized, placebo-controlled study assessing the efficacy and safety of epoetin- $\alpha$ in anemic patients with low-risk MDS. Leukemia. 2018; 32(12): 2648-2658, doi: 10.1038/s41375-018-0118-9, indexed in Pubmed: 29895954.

21. Platzbecker U, Symeonidis A, Oliva EN, et al. A phase 3 randomized placebo-controlled trial of darbepoetin alfa in patients with anemia and lower-risk myelodysplastic syndromes. Leukemia. 2017; 31(9): 1944-1950, doi: 10.1038/leu.2017.192, indexed in Pubmed: 28626220.

22. Park S, Kelaidi C, Meunier M, et al. The prognostic value of serum erythropoietin in patients with lower-risk myelodysplastic syndromes: a review of the literature and expert opinion. Ann Hematol. 2020; 99(1): 7-19, doi: 10.1007/s00277-019-03799-4, indexed in Pubmed: 31650290.

23. Santini V, Schemenau J, Levis A, et al. Can the revised IPSS predict response to erythropoietic-stimulating agents in patients with classical IPSS low or intermediate-1 MDS? Blood. 2013; 122(13): 2286-2288, doi: 10.1182/blood-2013-07-512442, indexed in Pubmed: 24072851.

24. Houston BL, Jayakar J, Wells RA, et al. A predictive model of response to erythropoietin stimulating agents in myelodysplastic syndrome: from the Canadian MDS patient registry. Ann 
Hematol. 2017; 96(12): 2025-2029, doi: 10.1007/s00277-0173137-0, indexed in Pubmed: 28975386.

25. Malcovati L, Hellström-Lindberg E, Bowen D, et al. European Leukemia Net. Diagnosis and treatment of primary myelodysplastic syndromes in adults: recommendations from the European LeukemiaNet. Blood. 2013; 122(17): 2943-2964, doi: 10.1182/ /blood-2013-03-492884, indexed in Pubmed: 23980065.

26. Garcia-Manero G, Chien KS, Montalban-Bravo G. Myelodysplastic syndromes: 2021 update on diagnosis, risk stratification and management. Am J Hematol. 2020; 95(11): 1399-1420, doi: 10.1002/ajh.25950, indexed in Pubmed: 32744763.

27. Greenberg PL, Sun Z, Miller KB, et al. Treatment of myelodysplastic syndrome patients with erythropoietin with or without granulocyte colony-stimulating factor: results of a prospective randomized phase 3 trial by the Eastern Cooperative Oncology Group (E1996). Blood. 2009; 114(12): 2393-2400, doi: 10.1182/ /blood-2009-03-211797, indexed in Pubmed: 19564636.

28. Hellström-Lindberg E, Birgegård G, Carlsson M, et al. A combination of granulocyte colony-stimulating factor and erythropoietin may synergistically improve the anaemia in patients with myelodysplastic syndromes. Leuk Lymphoma. 1993; 11(3-4): 221-228, doi: 10.3109/10428199309086999, indexed in Pubmed: 7505147.

29. Jädersten M, Malcovati L, Dybedal I, et al. Erythropoietin and granulocyte-colony stimulating factor treatment associated with improved survival in myelodysplastic syndrome. J Clin Oncol. 2008; 26(21): 3607-3613, doi: 10.1200/JCO.2007.15.4906, indexed in Pubmed: 18559873.

30. List A, Dewald G, Bennett J, et al. Myelodysplastic Syndrome-003 Study Investigators. Lenalidomide in the myelodysplastic syndrome with chromosome 5q deletion. N Engl J Med. 2006; 355(14): 1456-1465, doi: 10.1056/NEJMoa061292, indexed in Pubmed: 17021321.

31. Santini V, Almeida A, Giagounidis A, et al. Randomized phase III study of lenalidomide versus placebo in RBC transfusion-dependent patients with lower-risk non-del(5q) myelodysplastic syndromes and ineligible for or refractory to erythropoiesis-stimulating agents. J Clin Oncol. 2016; 34(25): 2988-2996, doi: 10.1200/JCO.2015.66.0118, indexed in Pubmed: 27354480.

32. Sibon D, Cannas G, Baracco F, et al. Groupe Francophone des Myélodysplasies. Lenalidomide in lower-risk myelodysplastic syndromes with karyotypes other than deletion $5 \mathrm{q}$ and refractory to erythropoiesis-stimulating agents. Br J Haematol. 2012; 156(5): 619-625, doi: 10.1111/j.1365-2141.2011.08979.x, indexed in Pubmed: 22211483.

33. Narla A, Dutt S, McAuley JR, et al. Dexamethasone and lenalidomide have distinct functional effects on erythropoiesis. Blood. 2011; 118(8): 2296-2304, doi: 10.1182/blood-2010-11-318543, indexed in Pubmed: 21527522.

34. McGraw KL, Basiorka AA, Johnson JO, et al. Lenalidomide induces lipid raft assembly to enhance erythropoietin receptor signaling in myelodysplastic syndrome progenitors. PLoS One. 2014; 9(12): e114249, doi: 10.1371/journal.pone.0114249, indexed in Pubmed: 25469886.

35. Adema V, Palomo L, Toma A, et al. Groupe Francophone des Myélodysplasies. A G polymorphism in the CRBN gene acts as a biomarker of response to treatment with lenalidomide in low/int-1 risk MDS without del(5q). Leukemia. 2013; 27(7): 1610-1613, doi: 10.1038/leu.2013.59, indexed in Pubmed: 23434730.

36. Komrokji RS. Activin receptor II ligand traps: new treatment paradigm for low-risk MDS. Curr Hematol Malig Rep. 2019;
14(4): 346-351, doi: 10.1007/s11899-019-00517-9, indexed in Pubmed: 31203517.

37. Komrokji RS. Luspatercept in myelodysplastic syndromes: who and when? Hematol Oncol Clin North Am. 2020; 34(2): 393-400, doi: 10.1016/j.hoc.2019.10.004, indexed in Pubmed: 32089218.

38. Platzbecker U, Germing U, Götze KS, et al. Luspatercept for the treatment of anaemia in patients with lower-risk myelodysplastic syndromes (PACE-MDS): a multicentre, open-label phase 2 dose-finding study with long-term extension study. Lancet Oncol. 2017; 18(10): 1338-1347, doi: 10.1016/S1470-2045(17)30615-0, indexed in Pubmed: 28870615.

39. Fenaux P, Platzbecker U, Mufti GJ, et al. Luspatercept in patients with lower-risk myelodysplastic syndromes. N Engl J Med. 2020; 382(2): 140-151, doi: 10.1056/NEJMoa1908892, indexed in Pubmed: 31914241.

40. Kantarjian H, Issa JPJ, Rosenfeld CS, et al. Decitabine improves patient outcomes in myelodysplastic syndromes: results of a phase III randomized study. Cancer. 2006; 106(8): 1794-1803, doi: 10.1002/cncr.21792, indexed in Pubmed: 16532500.

41. Fenaux P, Mufti GJ, Hellstrom-Lindberg E, et al. International Vidaza High-Risk MDS Survival Study Group. Efficacy of azacitidine compared with that of conventional care regimens in the treatment of higher-risk myelodysplastic syndromes: a randomised, open-label, phase III study. Lancet Oncol. 2009; 10(3): 223-232, doi: 10.1016/S1470-2045(09)70003-8, indexed in Pubmed: 19230772.

42. Musto P, Maurillo L, Spagnoli A, et al. Ad Hoc Italian Cooperative Study Group on Azacitidine in Myelodysplastic Syndromes Acute Leukemias. Azacitidine for the treatment of lower risk myelodysplastic syndromes: a retrospective study of 74 patients enrolled in an Italian named patient program. Cancer. 2010; 116(6): 1485-1494, doi: 10.1002/cncr.24894, indexed in Pubmed: 20151429.

43. Sanchez-Garcia J, Falantes J, Medina Perez A, et al. Grupo Andaluz SMD. Prospective randomized trial of 5 days azacitidine versus supportive care in patients with lower-risk myelodysplastic syndromes without $5 \mathrm{q}$ deletion and transfusion-dependent anemia. Leuk Lymphoma. 2018; 59(5): 1095-1104, doi: 10.1080/10428194.2017.1366998, indexed in Pubmed: 28836866.

44. Garcia-Manero G, Jabbour E, Borthakur G, et al. Randomized open-label phase II study of decitabine in patients with low- or intermediate-risk myelodysplastic syndromes. J Clin Oncol. 2013; 31(20): 2548-2553, doi: 10.1200/JCO.2012.44.6823, indexed in Pubmed: 23733767.

45. Jabbour E, Short NJ, Montalban-Bravo G, et al. Randomized phase 2 study of low-dose decitabine vs low-dose azacitidine in lower-risk MDS and MDS/MPN. Blood. 2017; 130(13): 1514-1522, doi: 10.1182/blood-2017-06-788497, indexed in Pubmed: 28774880.

46. Grinblatt DL, Sekeres MA, Komrokji RS, et al. Patients with myelodysplastic syndromes treated with azacitidine in clinical practice: the AVIDA registry. Leuk Lymphoma. 2015; 56(4): 887-895, doi: 10.3109/10428194.2014.935366, indexed in Pubmed: 24956145.

47. Tobiasson M, Dybedahl I, Holm MS, et al. Limited clinical efficacy of azacitidine in transfusion-dependent, growth factor-resistant, low- and Int-1-risk MDS: Results from the nordic NMDSG08A phase II trial. Blood Cancer J. 2014; 4: e189, doi: 10.1038/ /bcj.2014.8, indexed in Pubmed: 24608733.

48. Houwerzijl EJ, Blom NR, van der Want JJL, et al. Increased peripheral platelet destruction and caspase-3-independent programmed cell death of bone marrow megakaryocytes in myelodysplastic patients. Blood. 2005; 105(9): 3472-3479, doi: 10.1182/ /blood-2004-06-2108, indexed in Pubmed: 15542580. 
49. Tamura H, Ogata K, Luo S, et al. Plasma thrombopoietin (TPO) levels and expression of TPO receptor on platelets in patients with myelodysplastic syndromes. Br J Haematol. 1998; 103(3): 778-784, doi: 10.1046/j.1365-2141.1998.01054.x, indexed in Pubmed: 9858230

50. Fenaux P, Muus P, Kantarjian H, et al. Romiplostim monotherapy in thrombocytopenic patients with myelodysplastic syndromes: long-term safety and efficacy. Br J Haematol. 2017; 178(6): 906-913, doi: 10.1111/bjh.14792, indexed in Pubmed: 28616874.

51. Kantarjian H, Fenaux P, Sekeres MA, et al. Safety and efficacy of romiplostim in patients with lower-risk myelodysplastic syndrome and thrombocytopenia. J Clin Oncol. 2010; 28(3): 437-444, doi: 10.1200/JCO.2009.24.7999, indexed in Pubmed: 20008626.

52. Kantarjian HM, Sekeres MA, Ribrag V, et al. Subcutaneous or intravenous administration of romiplostim in thrombocytopenic patients with lower risk myelodysplastic syndromes. Cancer. 2011; 117(5): 992-1000, doi: 10.1002/cncr.25545, indexed in Pubmed: 20945323.

53. Sekeres MA, Giagounidis A, Kantarjian H, et al. Development and validation of a model to predict platelet response to romiplostim in patients with lower-risk myelodysplastic syndromes. Br J Haematol. 2014; 167(3): 337-345, doi: 10.1111/bjh.13037, indexed in Pubmed: 25039607.

54. Oliva EN, Alati C, Santini V, et al. Eltrombopag versus placebo for low-risk myelodysplastic syndromes with thrombocytopenia (EQoL-MDS): phase 1 results of a single-blind, randomised, controlled, phase 2 superiority trial. Lancet Haematol. 2017; 4(3): e127-e136, doi: 10.1016/S2352-3026(17)30012-1, indexed in Pubmed: 28162984 .

55. Corazza F, Hermans C, D'Hondt S, et al. Circulating thrombopoietin as an in vivo growth factor for blast cells in acute myeloid leukemia. Blood. 2006; 107(6): 2525-2530, doi: 10.1182/ /blood-2005-06-2552, indexed in Pubmed: 16317100.

56. Kantarjian HM, Fenaux P, Sekeres MA, et al. Long-term follow-up for up to 5 years on the risk of leukaemic progression in thrombocytopenic patients with lower-risk myelodysplastic syndromes treated with romiplostim or placebo in a randomised doubleblind trial. Lancet Haematol. 2018; 5(3): e117-e126, doi: 10.1016/ /S2352-3026(18)30016-4, indexed in Pubmed: 29396092.

57. Prica A, Sholzberg M, Buckstein R. Safety and efficacy of thrombopoietin-receptor agonists in myelodysplastic syndromes: a systematic review and meta-analysis of randomized controlled trials. Br J Haematol. 2014; 167(5): 626-638, doi: 10.1111/bjh.13088, indexed in Pubmed: 25155450.

58. Kantarjian HM, Giles FJ, Greenberg PL, et al. Phase 2 study of romiplostim in patients with low- or intermediate-risk myelodysplastic syndrome receiving azacitidine therapy. Blood. 2010; 116(17): 3163-3170, doi: 10.1182/blood-2010-03-274753, indexed in Pubmed: 20631375.

59. Greenberg PL, Garcia-Manero G, Moore M, et al. Phase 2 study of romiplostim in patients with low- or intermediate-risk myelodysplastic syndrome receiving azacitidine therapy. Blood. 2010; 116(17): 3163-3170, doi: 10.1182/blood-2010-03-274753, indexed in Pubmed: 20631375

60. Girmenia C, Candoni A, Delia M, et al. Infection control in patients with myelodysplastic syndromes who are candidates for active treatment: Expert panel consensus-based recommendations. Blood Rev. 2019; 34: 16-25, doi: 10.1016/j.blre.2018.10.002, indexed in Pubmed: 30448050.

61. Nachtkamp K, Stark R, Strupp C, et al. Causes of death in 2877 patients with myelodysplastic syndromes. Ann Hematol. 2016;
95(6): 937-944, doi: 10.1007/s00277-016-2649-3, indexed in Pubmed: 27025507.

62. Greenberg PL, Stone RM, Al-Kali A, et al. Myelodysplastic syndromes, version 2.2017, NCCN clinical practice guidelines in oncology. J Natl Compr Canc Netw. 2017; 15(1): 60-87, doi: 10.6004/ /jnccn.2017.0007, indexed in Pubmed: 28040720.

63. Biesma DH, van den Tweel JG, Verdonck LF. Immunosuppressive therapy for hypoplastic myelodysplastic syndrome. Cancer. 1997; 79(8): 1548-1551, doi: 10.1002/(sici)10970142(19970415)79:8<1548::aid-cncr16>3.0.co;2-y, indexed in Pubmed: 9118037.

64. Saunthararajah Y, Nakamura R, Wesley R, et al. A simple method to predict response to immunosuppressive therapy in patients with myelodysplastic syndrome. Blood. 2003; 102(8): 3025-3027, doi: 10.1182/blood-2002-11-3325, indexed in Pubmed: 12829603.

65. Haider M, Al Ali N, Padron E, et al. Immunosuppressive therapy: exploring an underutilized treatment option for myelodysplastic syndrome. Clin Lymphoma Myeloma Leuk. 2016; 16 (Suppl): S44-S48, doi: 10.1016/j.clml.2016.02.017, indexed in Pubmed: 27521323.

66. Passweg JR, Giagounidis AAN, Simcock M, et al. Immunosuppressive therapy for patients with myelodysplastic syndrome: a prospective randomized multicenter phase III trial comparing antithymocyte globulin plus cyclosporine with best supportive care - SAKK 33/99. J Clin Oncol. 2011; 29(3): 303-309, doi: 10.1200/JCO.2010.31.2686, indexed in Pubmed: 21149672.

67. Sloand EM, Wu CO, Greenberg P, et al. Factors affecting response and survival in patients with myelodysplasia treated with immunosuppressive therapy. J Clin Oncol. 2008; 26(15): 2505-2511, doi: 10.1200/JCO.2007.11.9214, indexed in Pubmed: 18413642.

68. Stahl M, DeVeaux M, de Witte T, et al. The use of immunosuppressive therapy in MDS: clinical outcomes and their predictors in a large international patient cohort. Blood Adv. 2018; 2(14): 1765-1772, doi: 10.1182/bloodadvances.2018019414, indexed in Pubmed: 30037803.

69. Shenoy N, Vallumsetla N, Rachmilewitz E, et al. Impact of iron overload and potential benefit from iron chelation in low-risk myelodysplastic syndrome. Blood. 2014; 124(6): 873-881, doi: 10.1182/blood-2014-03-563221, indexed in Pubmed: 24923296.

70. Zeidan AM, Griffiths EA. To chelate or not to chelate in MDS: that is the question! Blood Rev. 2018; 32(5): 368-377, doi: 10.1016/j. blre.2018.03.002, indexed in Pubmed: 29602612.

71. Malcovati L, Germing U, Kuendgen A, et al. Time-dependent prognostic scoring system for predicting survival and leukemic evolution in myelodysplastic syndromes. J Clin Oncol. 2007; 25(23): 3503-3510, doi: 10.1200/JCO.2006.08.5696, indexed in Pubmed: 17687155 .

72. Jin X, He X, Cao X, et al. Iron overload impairs normal hematopoietic stem and progenitor cells through reactive oxygen species and shortens survival in myelodysplastic syndrome mice. Haematologica. 2018; 103(10): 1627-1634, doi: 10.3324/haematol.2018.193128, indexed in Pubmed: 29903757.

73. Chacko J, Pennell DJ, Tanner MA, et al. Myocardial iron loading by magnetic resonance imaging $\mathrm{T} 2 *$ in good prognostic myelodysplastic syndrome patients on long-term blood transfusions. Br J Haematol. 2007; 138(5): 587-593, doi: 10.1111/j.13652141.2007.06695.x, indexed in Pubmed: 17610536.

74. Jensen PD, Jensen FT, Christensen T, et al. Relationship between hepatocellular injury and transfusional iron overload prior to and during iron chelation with desferrioxamine: a study in adult 
patients with acquired anemias. Blood. 2003; 101(1): 91-96, doi: 10.1182/blood-2002-06-1704, indexed in Pubmed: 12393528.

75. Gattermann N, Finelli C, Della Porta M, et al. Hematologic responses to deferasirox therapy in transfusion-dependent patients with myelodysplastic syndromes. Haematologica. 2012; 97(9): 1364-1371, doi: 10.3324/haematol.2011.048546, indexed in Pubmed: 22419577.

76. Jensen PD, Heickendorff L, Pedersen B, et al. The effect of iron chelation on haemopoiesis in MDS patients with transfusional iron overload. Br J Haematol. 1996; 94(2): 288-299, doi: 10.1046/ /j.1365-2141.1996.d01-1795.x, indexed in Pubmed: 8759889.

77. Improta S, Villa MR, Volpe A, et al. Transfusion-dependent lowrisk myelodysplastic patients receiving deferasirox: Long-term follow-up. Oncol Lett. 2013; 6(6): 1774-1778, doi: 10.3892/ /ol.2013.1617, indexed in Pubmed: 24260074.

78. Leitch HA, Parmar A, Wells RA, et al. Overall survival in lower IPSS risk MDS by receipt of iron chelation therapy, adjusting for patient-related factors and measuring from time of first red blood cell transfusion dependence: an MDS-CAN analysis. Br J Haematol. 2017 Oct. ; 179(1): 83-97.

79. Remacha ÁF, Arrizabalaga B, Villegas A, et al. IRON-2 Study Group. Evolution of iron overload in patients with low-risk myelodysplastic syndrome: iron chelation therapy and organ complications. Ann Hematol. 2015; 94(5): 779-787, doi: 10.1007/s00277014-2274-y, indexed in Pubmed: 25516455.

80. Rose C, Brechignac S, Vassilief D, et al. GFM (Groupe Francophone des Myélodysplasies). Does iron chelation therapy improve survival in regularly transfused lower risk MDS patients? A multicenter study by the GFM (Groupe Francophone des Myélodysplasies). Leuk Res. 2010; 34(7): 864-870, doi: 10.1016/j.leukres.2009.12.004, indexed in Pubmed: 20129667.

81. Mainous AG, Tanner RJ, Hulihan MM, et al. The impact of chelation therapy on survival in transfusional iron overload: a meta- -analysis of myelodysplastic syndrome. Br J Haematol. 2014; 167(5): 720-723, doi: 10.1111/bjh.13053, indexed in Pubmed: 25048454.

82. Angelucci E, Li J, Greenberg P, et al. TELESTO Study Investigators. Iron chelation in transfusion-dependent patients with low- to intermediate-1-risk myelodysplastic syndromes: a randomized trial. Ann Intern Med. 2020; 172(8): 513-522, doi: 10.7326/M190916, indexed in Pubmed: 32203980.

83. Komrokji R, Garcia-Manero G, Ades L, et al. Sotatercept with long-term extension for the treatment of anaemia in patients with lower-risk myelodysplastic syndromes: a phase 2, dose-ranging trial. Lancet Haematol. 2018; 5(2): e63-e72, doi: 10.1016/S23523026(18)30002-4, indexed in Pubmed: 29331635.

84. Steensma DP, Fenaux P, Van Eygen K, et al. Imetelstat achieves meaningful and durable transfusion independence in high transfusion-burden patients with lower-risk myelodysplastic syndromes in a phase II study. J Clin Oncol. 2021; 39(1): 48-56, doi: 10.1200/ /JCO.20.01895, indexed in Pubmed: 33108243.

85. Garcia-Manero G, Gore SD, Kambhampati S, et al. Efficacy and safety of extended dosing schedules of CC-486 (oral azacitidine) in patients with lower-risk myelodysplastic syndromes. Leukemia. 2016; 30(4): 889-896, doi: 10.1038/leu.2015.265, indexed in Pubmed: 26442612.

86. Garcia-Manero G, Scott BL, Cogle CR, et al. CC-486 (oral azacitidine) in patients with myelodysplastic syndromes with pretreatment thrombocytopenia. Leuk Res. 2018; 72: 79-85, doi: 10.1016/j.leukres.2018.08.001, indexed in Pubmed: 30114559.

87. Garcia-Manero G, McCloskey J, Griffiths E, et al. Pharmacokinetic exposure equivalence and preliminary efficacy and safety from a randomized cross over phase 3 study (ASCERTAIN study) of an oral hypomethylating agent ASTX727 (cedazuridine/decitabine) compared to IV decitabine. Blood. 2019; 134(Suppl_1): 846-846, doi: 10.1182/blood-2019-122980. 